\title{
Synthesis of Literature and Field Work Data Leading to the Compilation of a New Geological Map-A Review of Geology of Northwestern Greece
}

\author{
Dimitrios Ntokos \\ School of Mining and Metallurgical Engineering, National Technical University of Athens, Athens, Greece \\ Email: dntokos@mail.ntua.gr
}

How to cite this paper: Ntokos, D. (2017) Synthesis of Literature and Field Work Data Leading to the Compilation of a New Geological Map-A Review of Geology of Northwestern Greece. International Journal of Geosciences, 8, 205-236.

https://doi.org/10.4236/ijg.2017.82009

Received: November 30, 2016

Accepted: February 25, 2017

Published: February 28, 2017

Copyright $\odot 2017$ by author and Scientific Research Publishing Inc. This work is licensed under the Creative Commons Attribution International License (CC BY 4.0).

http://creativecommons.org/licenses/by/4.0/

\begin{abstract}
This paper presents the geological structure of the entire region of northwestern Greece (Epirus). Four geotectonic zones (Subpelagonian, Pindos, Gavrovo, and Ionian) develop in this area, overthrusting one another, their compression axes trending NE-SW. Normal, reverse, and strike-slip faults with main directions NNW-SSE, NE-SW, and E-W have influenced the geological formations. In the context of this paper, the results of all previous, relevant studies were considered, summarized and reviewed, in order to provide a brief historical recursion and present some of the most important discoveries made in the area, from 1840 until present. All these results were evaluated and combined, the geological formations were grouped according to their characteristics and field work enabled the confirmation or addition of new data, which led to the compilation of a new geological map, using GIS techniques, for the improved visualization of the geological and tectonic structure of northwestern Greece. This map illustrates a lot of new data, based on detailed geological-tectonic mapping, depicting the precise boundaries of the geological formations, detecting of Neogene and Quaternary sediments and evaluating fault activity. The knowledge and illustration of an area's geological structure constitute a dynamic tool for further scientific research and economic development.
\end{abstract}

\section{Keywords}

Geological Structure, Geotectonic Zones, Geological-Tectonic Mapping, Epirus

\section{Introduction}

The knowledge of geology of an area contributes to the exploration and exploita- 
tion of rocks and minerals with economic benefits, prognosis of natural disasters, evaluation, and overcome of environmental problems, definition of paleo-environmental conditions, successful construction of engineering works, etc. Therefore, the good understanding and knowledge of the geological structure of an area contribute variously to the improvement of human life quality and solution of its significant problems.

The geological structure of northwestern Greece (Epirus; Figure 1) is very complicated and complex as a result of many intense tectonic events (overthrusting, thrusting, folding, faulting). Since 1840 , this area has been studied by many researchers and a large number of geological formations have been identified and examined. Different views about the geological conditions have been put forward. These views have been evaluated, summarized, synthesized, and reviewed in this paper. New data from field work observations have been added, resulting in modification of geological boundaries, identification of their main characteristics,

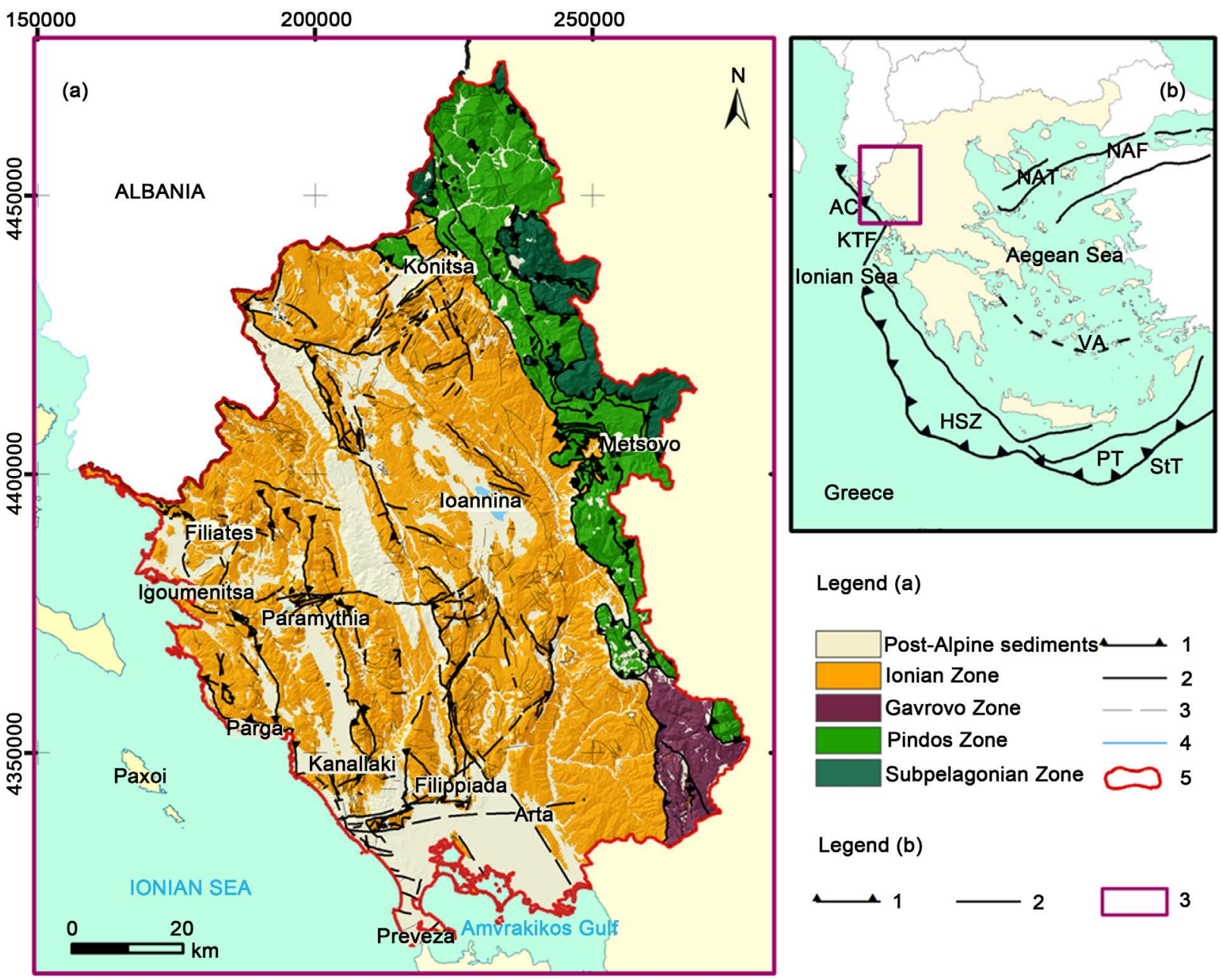

Figure 1. (a) Map of the Geotectonic Zones in northwestern Greece (study area): 1-Thrust and Overthrust, 2-Visible Fault, 3Probable or Covered Fault, 4-River, 5-Study Area; (b) The major structures of the Hellenic arc are indicated: HSZ-Hellenic Subduction Zone, AC_-Adriatic Collision, KTF-Kefalonia Transform Fault, PT_Pliny Trench, StT_Strabo Trench, VA-Volcanic Arc, NAT-North Aegean Trough, NAF-North Anatolian Fault, 1-Thrust and Overthrust, 2-Tectonic Structure, 3Study area. 
definition of the strike and dip of beds, comparison and correlation of different geological formations. Based on the existing literature data and the field work results, the geological formations have been grouped. Neotectonic mapping has been carried out based on field observations, fault mapping and tectonic analysis computing the orientations of the stress axes. All above-mentioned works have resulted in the compilation of two maps at 1:100,000 scale, by GIS techniques:

(a) A map showing the distribution of geotectonic zones (Figure 1), and

(b) A new geological map of northwestern Greece (Epirus; Figure 2).

The region of Epirus covers an area of $9203 \mathrm{~km}^{2}$ and it constitutes $6.97 \%$ of Greek territory. Epirus is characterized by a sharp relief and a plenty of surface waters. Pindos, being the major mountain chain of Greece, dominates and its highest point has an altitude of $2637 \mathrm{~m}$. The plains (25.8\%) are limited to the areas of Arta and Preveza and along the rivers of Acheron and Kalamas. The mountains occupy a percentage of $74.2 \%$ of the total area while high dips and deep valleys (e.g. Vikos, Arachthos and Acherontas) are identified. Some of the most important mountains of Epirus are as follows: Smolikas (2637 m), Grammos (2520 m), Tymfi (or Gamila, $2497 \mathrm{~m}$ ), Athamanian Mountains (or Tzoumerka, 2393 m), Lakmos (or Peristeri, 2295 m), Douskos (Nemertsika or Meropi, $2198 \mathrm{~m}$ ), Tomaros (1974 m), Valtos Mountains (1852 m), Mitsikeli (1810 m), Mourgana (1806 m), Souli Mounts $(1615 \mathrm{~m})$ etc. Significant rivers may be referred to the following ones: Aoos, Arachthos, Kalamas (or Thyamis), Louros, and Acherontas. A significant element of the hydrogeological situation of Epirus constitutes the Pamvotis Lake (or Ioannina Lake). The watershed of the water district of Epirus is defined by the Amvrakikos Gulf in the south and it continues northwards along the Mountains of Valtos, Athamanian, Northern Pindos, and Grammos. Finally, the northern boundaries of this water district are defined by the Greek-Albanian borders.

Epirus is made up of the geological formations belonging to the Subpelagonian, Pindos, Gavrovo, and Ionian Geotectonic Zones as well as of post-alpine formations [1]. The Ionian Zone dominates (percentage by 78\%) in the northwestern Greece area. The geotectonic Zones of Pindos, Gavrovo, and Subpelagonian occupy $12 \%, 5.6 \%$, and $4.4 \%$ of the total area respectively (Figure 1 ).

\section{Historical Recursionand Summary of Previous Geological Researches}

During $19^{\text {th }}$ century, Boué [2], Viquesnel [3], and Neumayr [4] were the first geologists who studied the geological conditions in Epirus. Philippson [5] [6] [7] [8] [9] examined the whole structure of Epirus identifying the thrusted Pindos Zone over the Ionian Zone and the vertical axis level of folds in the eastern half part of Epirus.

During the first half of $20^{\text {th }}$ century, Renz [10]-[15] established the stratigraphic regime in western Greece confirming the Pindos ovethrust and identifying the overthrust sheets towards the west. Brunn [16] showed the inclination of the Mitsikeli anticline eastwards.

Aubouin [17] [18] [19] compiled the first geological study for the whole Ionian 


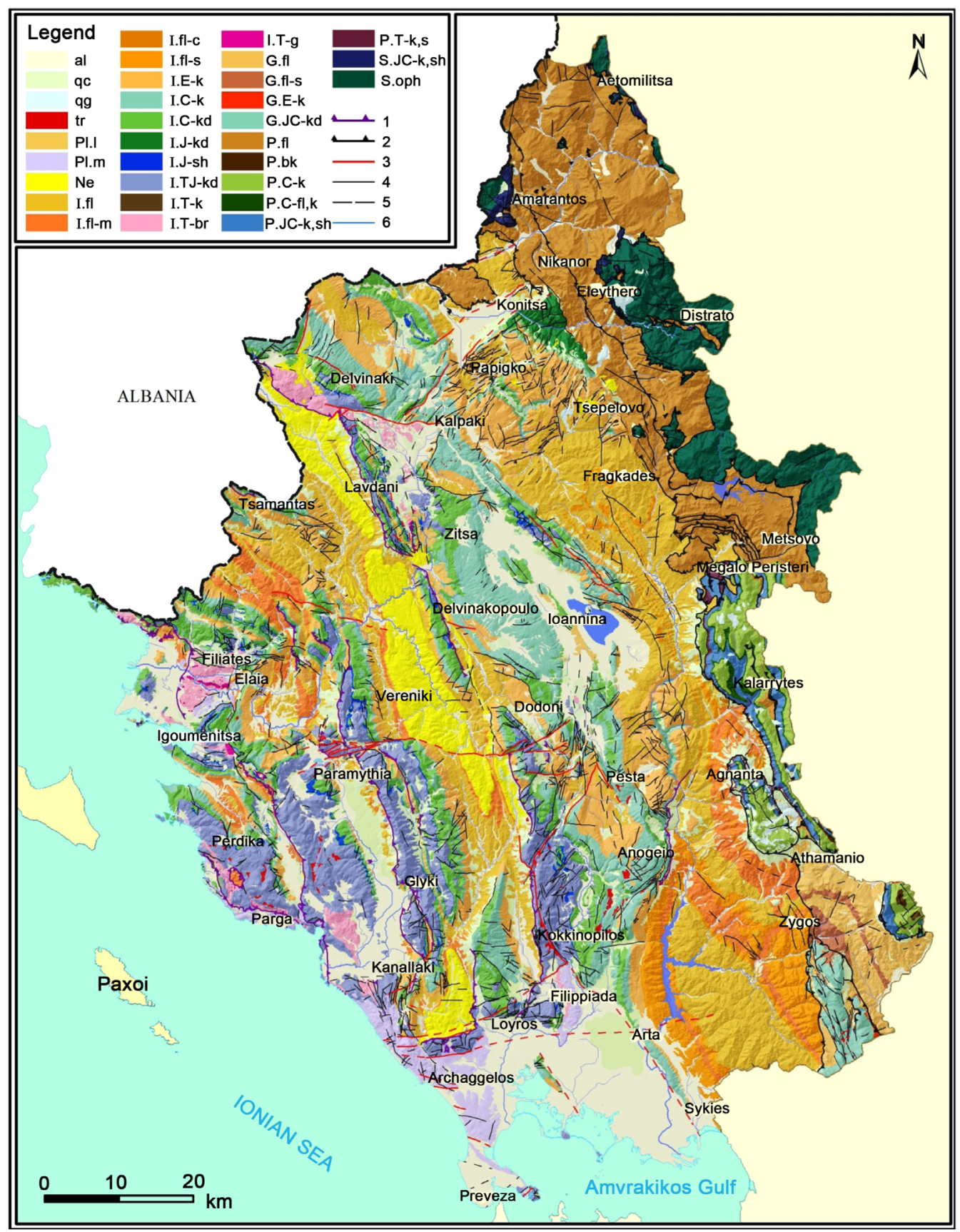

Figure 2. Geological map of northwestern Greece: Quaternary (al-Alluvial Deposits, $q c$-Scree and Talus Cones , $q g$-Glacial Deposits and Moraines, tr-Terra Rossa, Pl.l-Plio-Pleistocene Lacustrine Sediments, Pl.m-Plio-Pleistocene Marines Sediments, Neogene Formations (Ne-Marine Molasse, Marls and Sandstones), pre-Neogene Bedrock (Ionian Zone: I.fl-Flysch, I.fl-m-Flysch-mainly Marls, I.fl-c-Flysch-mainly Conglomerates, I.fl-s-Flysch-mainly Sandstones, I.E-k-Paleocene-Eocene Limestones, I.C-k-Upper Sennonian Limestones, I.C-kd-Vigla Limestones, I.J-kd-Limestones with Filaments, I.J-sh-Upper/Siliceous Shales with Posidonia, I.TJ-kd-Pantokratoras Limestones, I.T-k-Upper Triassic Limestones, I.T-br-Triassic Breccias, I.T-g-Gypsum; Gavrovo Zone: G.fl-Flysch, G.fl-s-Flysch-mainly Sandstones, G.E-k-Paleocene-Eocene Limestones, G.JC-kd-Cretaceous Limestones; Pindos Zone: P.fl-Flysch of the Pindos Zone, P.bk-Series of Transition Beds, P.C-k-Pelagic Platy Limestones, P.C-fl,k-First Flysch of Pindos Zone, P.JC-k,sh-Schist-Chert Formation, P.T-k,s-Triassic Clastic Formation; Subpelagonian Zone: S.JC-k,shSchist-Chert Formation, S.oph-Ophiolitic Masses), 1-Potencially Active Thrust, 2-Thrust and Overthrust, 3-Active Fault, 4-Visible Fault, 5-Probable or Covered Fault, 6-River. 
Zone in the western continental Greece, divided it into Internal, Central, and External (from east to west) and analyzed its stratigraphy and tectonics. He studied the tangential structures and showed that Epirus is made up of syncline and anticline structures which overthrust towards the west while the eastern anticlines incline eastwards. He also indicated the existence of strike-slip faults considering that these faults are older than folds and overthrusts. Finally, he determined the age of this overthrust tectonic activity in the Middle-Upper Miocene period.

Researchers from Institute of Geology and Subsurface Research-IGRS and Institut Francais du Petrole-IFP examined the presence of normal faults of Jurassic age in the Ionian Zone for first time [20]. These faults were created by an extended extensional stress field resulted in the first tectonic deformation on the Early Lias limestones (known as Pantokratoras limestones; Figure 3 and Figure 4) in that period. In 1966, the same scientific team studied in details the tectonic setting for the entire Epirus compiling an excellent map at scale 1:100,000 and distinguished three successive compressional periods: Aquitanian-Burdigalian, Late Burdigalian (main tectonic phase) and Mio-Pliocene-Quaternary.

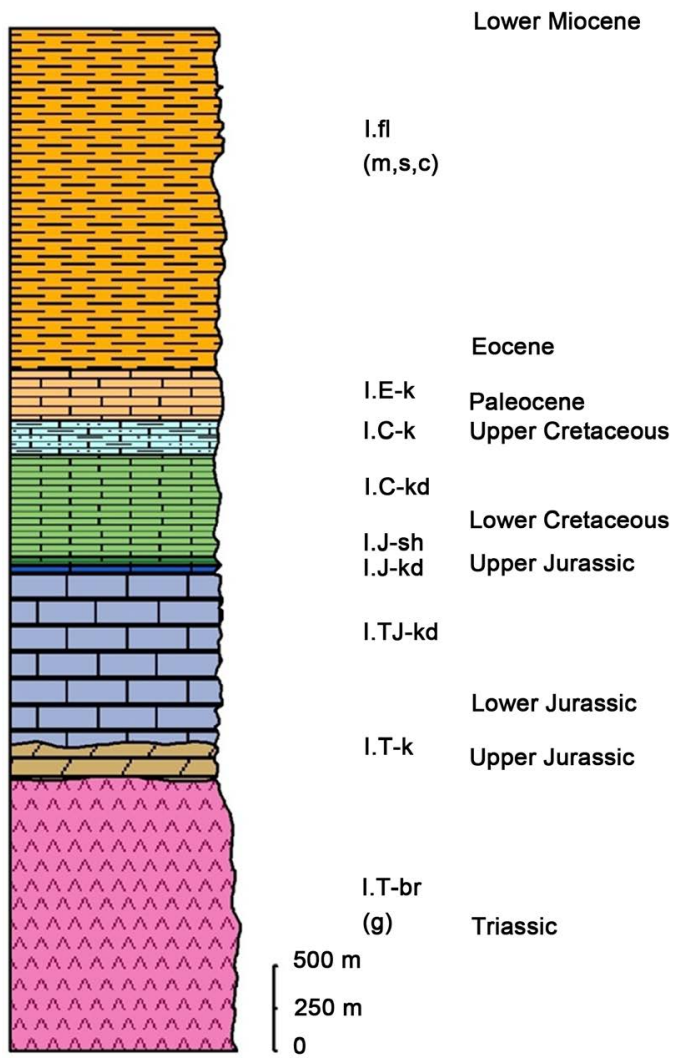

Figure 3. Lithostratigraphic column of the Ionian Zone, illustrating the geological formations that crop out in the study area and are presented in the Geological mapon Figure 2: I.fl-Flysch, I.fl-m-Flysch-mainly Marls, I.fl-c-Flysch-mainly Conglomerates, I.fl-s-Flyschmainly Sandstones, I.E-k-Paleocene-Eocene Limestones, I.C-k-Upper Sennonian Limestones, I.C-kd-Vigla Limestones, I.J-kd-Limestones with Filaments, I.J-sh-Upper/Si- liceous Shales with Posidonia, I.TJ-kd-Pantokratoras Limestones, I.T-k-Upper TriassicLimestones, I.T-br-Triassic Breccias, I.T-g-Gypsum. 


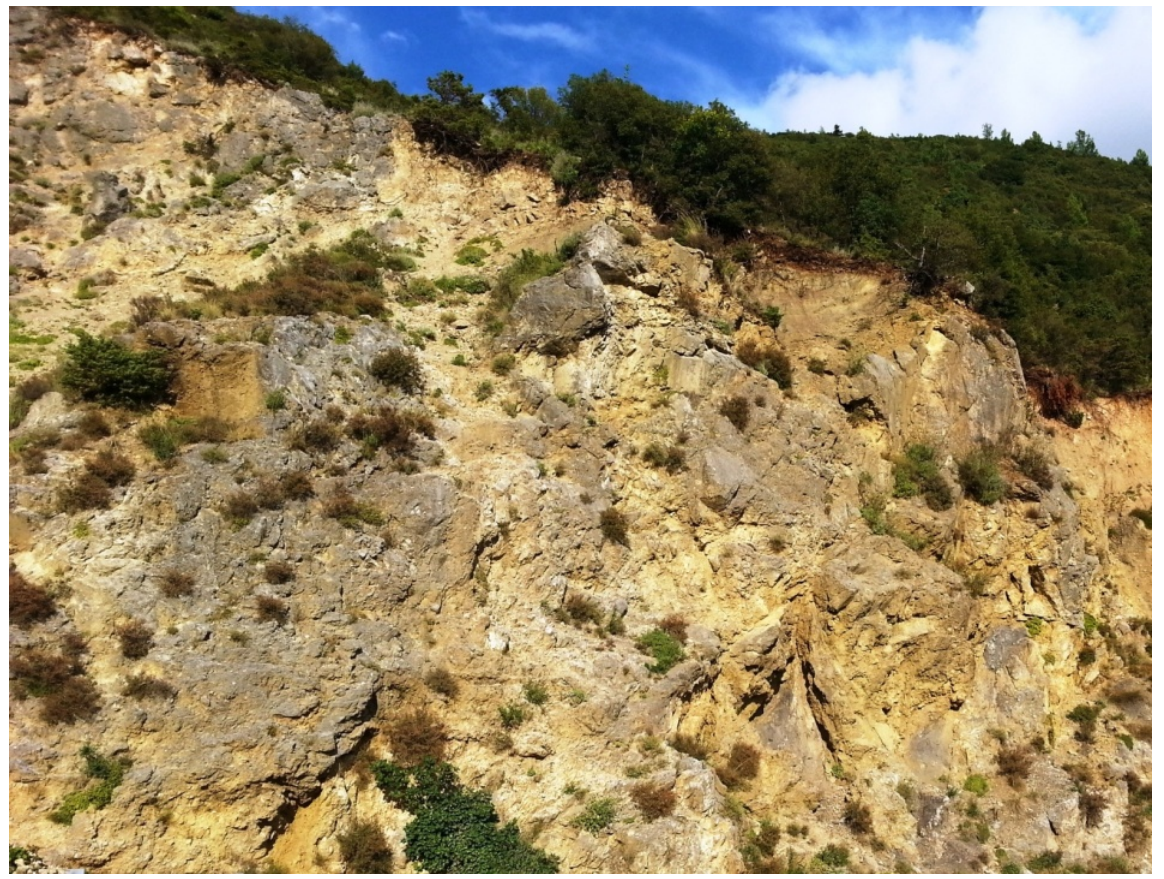

Figure 4. Pantokratora limestones as occur in Paramythia area.

Bernoulli and Renz [21] presented new sedimentary and stratigraphy data regarding the Jurassic formations in Epirus. In the context of hydrocarbon exploration in western Greece, the scientific team of British Petroleum-B.P. Co [22] provided important results about Epirus, identifying significant thrusts oriented in N-S to NW-SE directions and complicated groups of folds and faults. The halokinesis (diapiric movement) contributed to the tectonic deformation of this area, since the thick evaporite layer created a deep fracture and detachment zone.

Pomoni-Papaioannou [23] [24] and Karakitsios [25] noted that the Triassic breccias were formed from the dissolution of the subsurface Ionian evaporites. Guzzetta [26] controverted the tectonic interpretation after IGRS-IFP [20] and proposed a thick-skinned deformation which is characterized by rootless faults and high dip thrusts up risen from a main detachment surface located at the evaporite level. Similar interpretation was attributed by B.P. Co [22], Jenkins [27], and Sorel [28].

King [29] examined a micro-earthquake series whose focal mechanisms are associated with the complicated deformation due to local heterogeneities in the stress regime and small scale changes since the tectonic movement of Apulian micro-plate in north Ionian Sea causes compression and shortening of the crust in this area.

Pomoni-Papaioannou [30] [31] studied the petrography and sedimentalogy of the Triassic evaporites in Epirus. Underhill [32] [33] [34] reconsidered the previous options regarding the crustal deformation in western Greece as a result of the gravity sliding of Mesozoic formations over an evaporite layer and suggested that these deformations have been derived from sliding over shallow surfaces without simultaneous rapid uprising or sinking of the crustal rocks. 
Horner [35] noted a dextral rotation of the area based on paleomagnetic data from Eocene-Paleocene limestones. Kissel [36] agrees with this rotation around a vertical $50^{\circ}$ axis based on results of paleomagnetic measurements in Oligocene flysch. The rotation was performed during Lower-Middle Miocene by $25^{\circ}$ and Plio-Quaternary by $25^{\circ}$ too. Rotation by $45^{\circ}$ corresponds to an estimated departure by $130 \mathrm{~km}$ in southern Epirus. Tectonic structures follow the same rotation comparing them with the results from paleomagnetic studies.

According to Doutsos [37] [38], the sediments in the Preveza-Archaggelos basin have been influenced by fault systems with high dip angles. The active strike-slip faults are very rare, while faults in an almost E-W direction have contributed to the creation of the Amvrakikos Gulf. The tectonic activity during Neogene is attributed to a combination among overthrust movements, local diapirism, and extensive stresses [39] leading to the creation of sedimentary basins.

Karakitsios [40] [41] determined the formation of the Louros limestones (Middle Lias), provided new data about the stratigraphy of the Foustapidima limestones(Upper Triassic)and noted that many normal faults re-activated as reverse faults or thrust surfaces affected by alpine orogenic-compressional forces during Oligocene. Clews [42] suggested two tectonic phases in the period of Upper Pliocene-Quaternary: an extensional phase in N-S direction during Upper Pliocene and a post-Pliocene compressional phase in NW-SE direction.

Sorel [43] considered an alternation of compressional and extensional phases in E-W and N-S directions respectively in western Greece. The wider area has been deformed by three intense short-time compressional phases $\left(1^{\text {st }}\right.$ phase before 16 $15 \mathrm{Ma}, 2^{\text {nd }}$ before 4 - $3 \mathrm{Ma}$ and $3^{\text {rd }}$ before 1 - $0.7 \mathrm{Ma}$ ) since Miocene. Among them, long-time periods of tectonic stability have been intercalated. After the end of the third phase till nowadays, a continuous reduction of the compressional stresses has been noted in northwestern Greece.

Karakitsios [44]-[50] defined in details the stratigraphy of the Ionian Zone with scientific publications during 1988-1995. He signalized the contribution of diapirism to the sedimentation and tectonics, studied its evolution and considered that the Ionian Zone constitutes an example of reverse graben with evaporites as substratum. During 1990, 1992, and 1995, he noted that the pre-existing normal fault systems of Jurassic age re-activated as reverse faults during Burdigalian. Listric faults of Jurassic age were transformed to reserve faults, thrusts or strike-slip faults. A detachment at the evaporite level was identified. Due to halokinesis, the reverse movement was carried out only in the upper part of the faults and therefore, the re-activation partially followed the typical reverse tectonics.

Rondoyanni [51] provided new data about the stratigraphy and tectonics of Plio-Pleistocene deposits in the Preveza area. Waters [52] studied the deformation and tectonic evolution of northwestern Greece and considered the induced movement as a result of deep invisible tectonic structures (sinking thrusts and folds) based on geophysical, stratigraphical, and tectonic data. Karakitsios [53] examined unconformities and paleokarst phenomena of Jurassic age in the Ionian Zone. 
Nikolaou [54] correlated the surface manifestations of hydrocarbons with the dominated subsurface tectonic structures in Epirus. Paschos [55] studied the geodynamic evolution of south Epirus since Miocene, focusing on the stratigraphy and tectonics of Neogene and Quaternary sediments.

In addition, a plenty of scientific publications have contributed to the better understanding of the geological structure of northwestern Greece. Among them, the publications of Nikolaou [56], Caputo [57], Skourtsis-Coroneou [58] [59], Kamberis [60] [61], Getsos [62] [63], and Karakitsios [64] can be referred.

\section{Geological Structure of Northwestern Greece}

As it has been above-mentioned, Epirus is made up of geological formations belonging to the Subpelagonian, Pindos, Gavrovo, and Ionian Zones (from east to west), and sediments of Upper Eocene-Quaternary age deposited over them. A detailed description of the geological formations and lithostratigraphic structure of each zone based on previous studies (since 1840) and personal field observations follows. These formations have been grouped and the lithostratigraphical columns, which correspond to this grouping, are presented for each zone. The distribution of these formations is illustrated in the geological map of Figure 2. This map has been compiled by GIS techniquescombing new field data, produced by geological-tectonic mapping [1], with geological maps published by the Institute of Geology and Mineral Exploration-IGME at a 1:50,000 scale [65]-[88].

Particularly in terms of the correct approach of thegeological structure of northwestern Greece, apart from gathering all the relevant literature, the study focused on detailed geological-tectonic mapping, identifying the following:

(a) The lithological types of all the formations constituting the area's lithology,

(b) The common features of such formations, apart from their age, for the purpose of grouping them correctly,

(c) The locations of geological boundaries, as in several cases field observations showed that the boundaries differed from the relevant locations illustrated in existing maps, and

(d) The tectonic structures which were grouped in faults, folds and overthrusts and classified-evaluated as to their activity degree, inactive, potentially active, and non active.

Notably, the background of the map is the area's terrain in 3D form, as produced by the ArcGIS software (source: www.esri.com), for the reader's improved understanding and the optimum illustration of the real picture.

Specifically, combining and synthesizing all the literature and the field work data emerged the following geological formations.

\subsection{Post-Alpine Sediments}

The post-alpine sediments of Epirus include:

(a) Molassic formations of Upper Eocene-Miocene age deposited in the $\mathrm{Me}$ sohellenic Trough [66] [84] [86] [89] between the Zones of Subpelagonian and Pindos, and 
(b) Neogene and Quaternary sediments overlying unconformably the alpine formations and the molassic formations in grabens and erosional basins.

The Neogene and Quaternary sediments occupy the basin of Ioannina and large part of southern Epirus (e.g. areas of Arta, Preveza, Parga etc.). In general, rapid changes of lithological phases, horizontally and vertically, with parallel changes of terrestrial, marine and lacustrine facies in the formations of the same age as a result of neotectonic activity in combination with morphogenetic processes. The Neogene and Quaternary sediments have a variable thickness and contribute significantly to the development of aquifers [51] [90].

The Quaternary sediments consist of Holocene and Pleistocene deposits:

(a) The Holocene sediments occur in wide extent and include dunes and coastal sands, creeping and landsliding materials, shoals (rich in organic material), scree (Figure 5), talus cones ( $q \mathcal{c}$, as shown in the map of Figure 2) and alluvial deposits-al along the river valleys. The alluvial deposits consist of pebbles of various size and lithological composition and occur along the rivers and streams covering low slope areas at mountains or plains. Additionally, the Holocene sediments include scree and talus cones occurring in a wide extent and having a significant thickness. They are located near fractured structures and cover parts of slopes at mountainous areas as well as parts of river beds and river and torrent mouths. They constitute unconsolidated sediments with brown-colored clayey-sandy cement and calcareous rubbles of various sizes. Along the coastal area, between Parga and Preveza, marine deposits (sands, sandy silts, loams) occur at various altitudes forming elongated peneplation surfaces.

(b) The Pleistocene sediments are represented by glacial deposits- $q g$ of Wurm and Riss age [18]. The Wurm glacial deposits are observed as semi-circular valleys at altitudes higher than $1900 \mathrm{~m}$. They constitute scree and talus cones. During

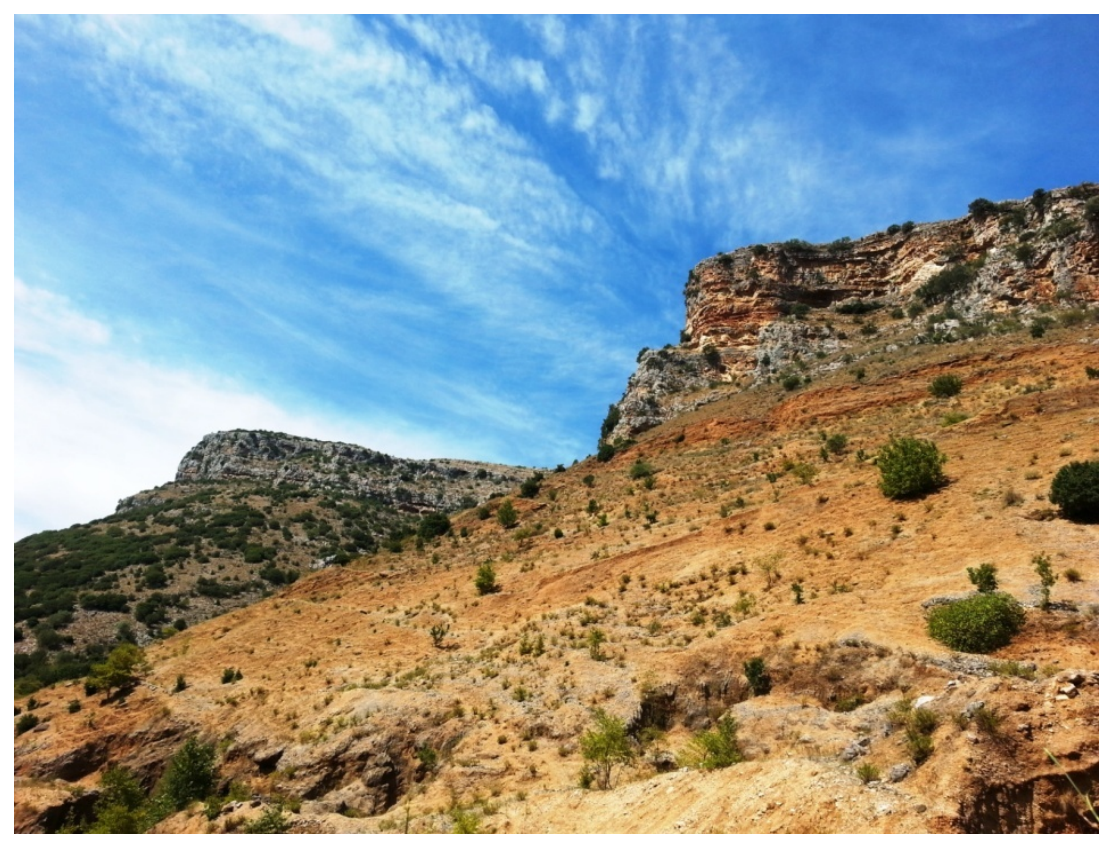

Figure 5. Scree overlying Upper Sennonian limestones in the Elaia area (near Fliates). 
Riss, a glacier phase took place creating glacial deposits as moraines (at altitudes up to $1400 \mathrm{~m}$ ) and glacier valleys (altitudes higher than $1900 \mathrm{~m}$ ) forming old scree. In addition, deposits of internal basins (terra rossa-tr, Figure 6), of Pleistocene age (200,000 - 250,000 years ago) [91], composed of red clays with thin layers of cherty rubbles which occur horizontal form [92]. In the Ioannina basin, thick lacustrine sediments-PI.I (clays, marls, clayey silts, lacutrine limestones) including lignite layers [93] have been deposited during whole Pleistocene. Significant Plio-Pleistocene sediments-Pl.m occurs in the Filippiada area and north of Preveza and Archagelos. Rapid changes of the environment of sedimentation (marine, brackish, lacustrine) and lateral transitions are observed. These sediments consist of:

(a) Clays, sands, marls, conglomerates and rubbles-pebbles, of Upper Pliocene-Lower Pleistocene age, and

(b) Clays and clay-marls $(\mathrm{Ne})$ of Upper Miocene-Lower Pliocene (Seravallian) age with intercalations of crystalline gypsum occurring in the area Riza-Kastrossykia, northwestern of Preveza.

In the Preveza-Loutsa area, the Neogene formations have been deformed intensely resulting in creation of folds in which the axes have a NW-SE direction. Minor occurrences of Neogene sediments are observed in the areas of Konitsa, Delvinaki, Parapotamos and Parga.

In the Subpelagonian Zone, towards the Pindos Zone, a large trough was formed during the final orogenetic activity of Upper Eocene age, in which very thick molassic sediments were deposited during Oligocene-Middle Miocene. This is the Mesohellenic Trough-mt extended in a NW-SE direction from the Greek-Albanian borders to the areas of Kastoria, Grevena, Kalampaka and south-

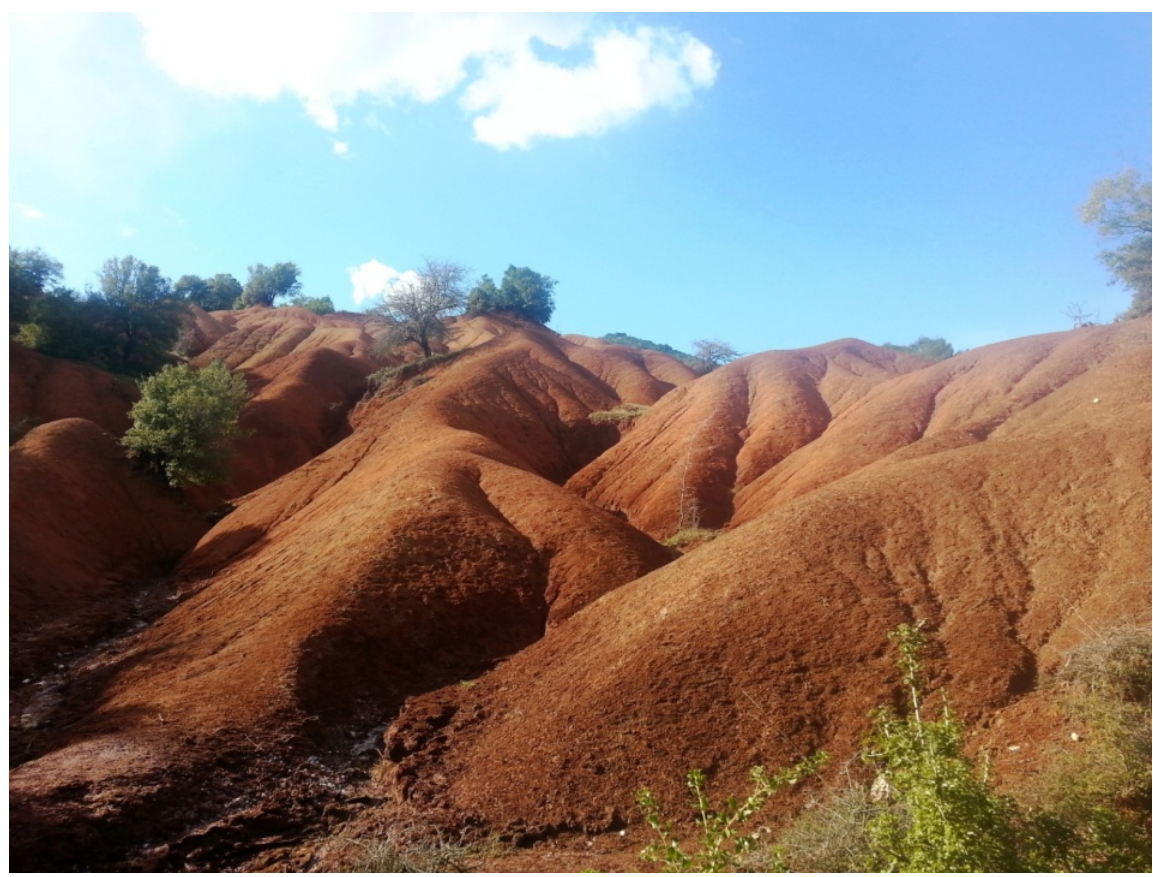

Figure 6. Deposits of terra rossa in the Kokkinopilos area (near Arta). 
wards [16] [94]. The molassic sediments cover the boundary between the Subpelagonian and Pindos Zones and are deposited on either very thick ophiolites (mainly) or Mesozoic limestones [89] [95]. They consist of transgressive conglomerates and breccias, alternations of siltstones and sandstones, consecutive layers of marls and siltstones. In Epirus, the Mesohellenic trough formations occur in the subbasin of the Sarantaporos River (near Konitsa) and include of the following formations [65] [89] [96].

(a) Eptachorio Formation of Oligocene age. It consists of upper beds (marls with thin sandstone intercalations, intermediate sandstones, lower marls), transition beds (blue or green-yellow silty marls alternating with fine-grained to micro-conglomeratic sandstones) and base layers (alternations of polygenetic conglomerates with fine-grained to micro-conglomeratic sandstones and marls). In this formation, consecutive layers of marls-siltstones and mainly grey-blue coloured siltstones dominate, while sandstones have a smaller participation and conglomerates even smaller.

(b) Pentalofos Formation of Oligocene-Lower Miocene (Aquitanian) age. It consists of sandstone series with polygenetic conglomerates, upper series of conglomerates and sandstones (cohesive marls and fine-grained marly sandstones), intermediate marls, polygenetic conglomerates and sandstones.

\subsection{Subpelagonian Zone}

The Subpelagonian Zone [18], extended in a NW-SE direction, occupy a very small part (4.4\%) in the northeastern side of Epirus (Figure 1(a)). Its main characteristic is the presence of large ophiolitic masses-S.oph and the accompanied schist-chert formation-S.JC- $k$,sh. The ophiolites are characterized as the western (external) ophiolitic zone of Greece, and so it is suggested that the Subpelagonian and Pindos Zones originate from the same ocean area [97] (Figure 7).

The ophiolites mainly consist of peridotites and serpentinites and are accompanied by red cherts. The ophiolites of the Kastanea overthrust sheets accompanied by cherts are dated as of Jurassic age.

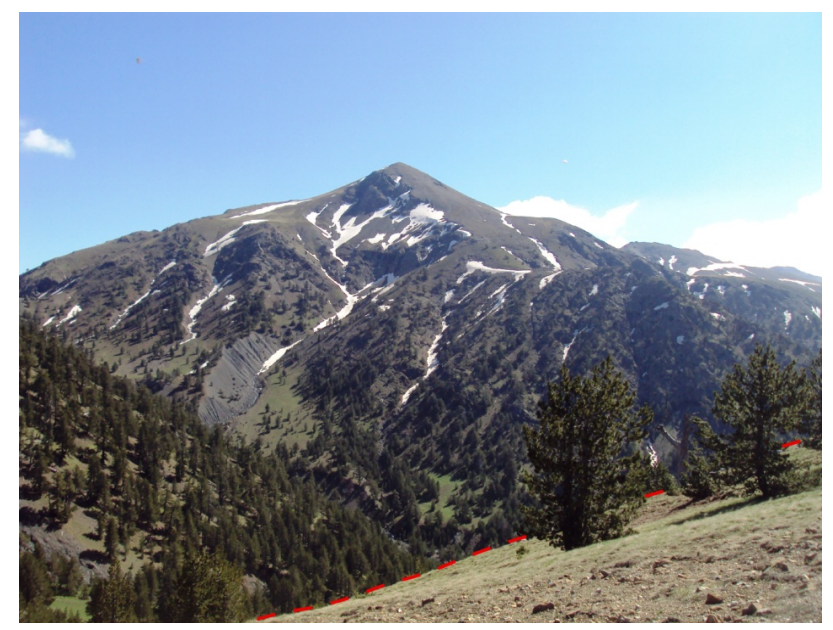

Figure 7. Ophiolitic masses tectonically placed on the flysch of the Pindos Zone as occur in Drakolimni at Mount Smolikas (with red line marked the geological boundary). 


\subsection{Pindos Zone}

The Pindos Zone [18] with a NW-SE direction occupies a small part (12.2\%) of the SE side of Epirus including the biggest part of its mountainous area (Figure 1(a)). It is extended from the Greek-Albanian borders to the Pindos mountain chain including the Mts Grammos (northern Pindos), Lakmos (northern Pindos) and Athamanian (Tzoumerka). Palaeo-geographically, Pindos constituted a very large marine basin of great depth (Figure 8). The Pindos Zone is suggested as a tectonic nappe overthrusted on the Gavrovo Zone westwards (exceeding $100 \mathrm{~km}$ at some locations) and it is known as Tectonic nappe of Pindos [89] [98]. In the northern part, the overthrusted nappe of Pindos has fully covered the Gavrovo Zone and it is observed tectonically on the Ionian Zone directly [99]. It is characterized by the presence of overthrust sheets from east to west forming continuous repetitions of the geological formations of this zone and they are mainly caused by tangential compressional tensions [18]. The rocks of the Pindos Zone have been folded intensely forming multi-numerous close, inclined and overturned folds and many fronts of thrusts and reverse faults are observed along the tectonic nappe of Pindos [85]. The age of the Pindos Zone formations is of Triassic-Upper Eocene. The oldest stratigraphically formation of the Pindos Zone is a Triassic clastic formation-P.T- $k, s$ consisting of (a) sandstones, cherts, marls, and limestones of Middle Triassic age, and (b) calcite turbidites, limestones (platy to thin-platy, marly, grey-black to black coloured), cherts (red to black), clayey marls, sandstones (green) and volcano-sedimentary materials (andesites, tuffs, basalts) of Middle-Upper Triassic age. These formations have been multi-folded [100].

The schist-chert formation-P.JC-k,sh of Jurassic age is composed of multicoloured cherts (radiolaritic, blue, green, brown, red and black coloured), clays, sandstones, siliceous limestones, and red cherts. The lower members consist of
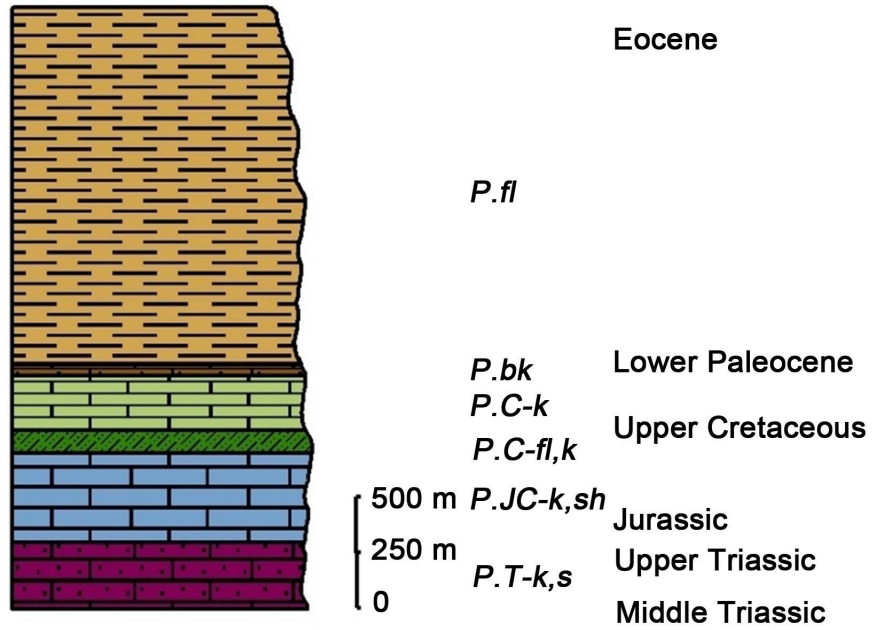

Figure 8. Lithostratigraphic column of the Pindos Zone, illustrating the geological formations that crop out in the study area and are presented in the Geological mapon Figure 2: P.fl-Flysch of the Pindos Zone, P.bk-Series of Transition Beds, P.C-k-Pelagic Platy Limestones, P.C-fl,k-First Flysch of Pindos Zone, P.JC-k,sh-Schist-Chert Formation, $P . T-k, s$-Triassic Clastic Formation. 
alternations of red platy limestones and cherts with gradual transition towards marly limestones (grey to white coloured) and decreased presence of cherts (Upper Triassic-Lias). The multicoloured cherts with thin layers of clayey-siliceous material, pellites, and limestones constitute the characteristic stratigraphic horizon of the Pindos Zone of Dogger-Tithonian age. Limestones with Calpionella of Upper Tithonian-Valanginian age consist of (a) red and yellow-green limestones including red-green cherts, in the lower members, and (b) red limestones with thin layers of clayey-marly material and cherts as well as brecciated limestones and calc-limestones including cherts, in the upper members [85].

On the schist-chert formation, the called first flysch of Pindos Zone-P.C-fl, $k$ has been developed. This flysch consists of (a) alternations of marls, radioralites, cherts, and marly schales, (b) sandstones, (c) pelagic sandstone, brecciated limestones, and pellites of Lower Cretaceous age. The pelagic platy limestones-P.C-k with siliceous material layers (cherts) of Upper Cretaceous age constitute the result of carbonate sedimentation, which took place during this period without any interruption and unconformity [89] [98] [101] (Figure 9).

A series of transition beds-P.bk of Late Cretaceous (Maestrichtian-Danian) age is composed of alternations of platy limestones, sandstones, and shales (Figure 10). Limestones dominate in the lower members of this series, while sandstones prevail in the upper ones. It constitutes a calc-marly series which is transitional towards the flysch.

The flysch-P.fl formed during Danian/Lower Pliocene-Upper Eocene is called as second flysch (or flysch) of the Pindos Zone in contrast with the Lower Cretaceous first flysch of the same zone. It constitutes the main flysch and consists of rhythmic alternation of sandstones and marls with local conglomerates (lenticular layers of small thickness) and limestones. It is considered as the most

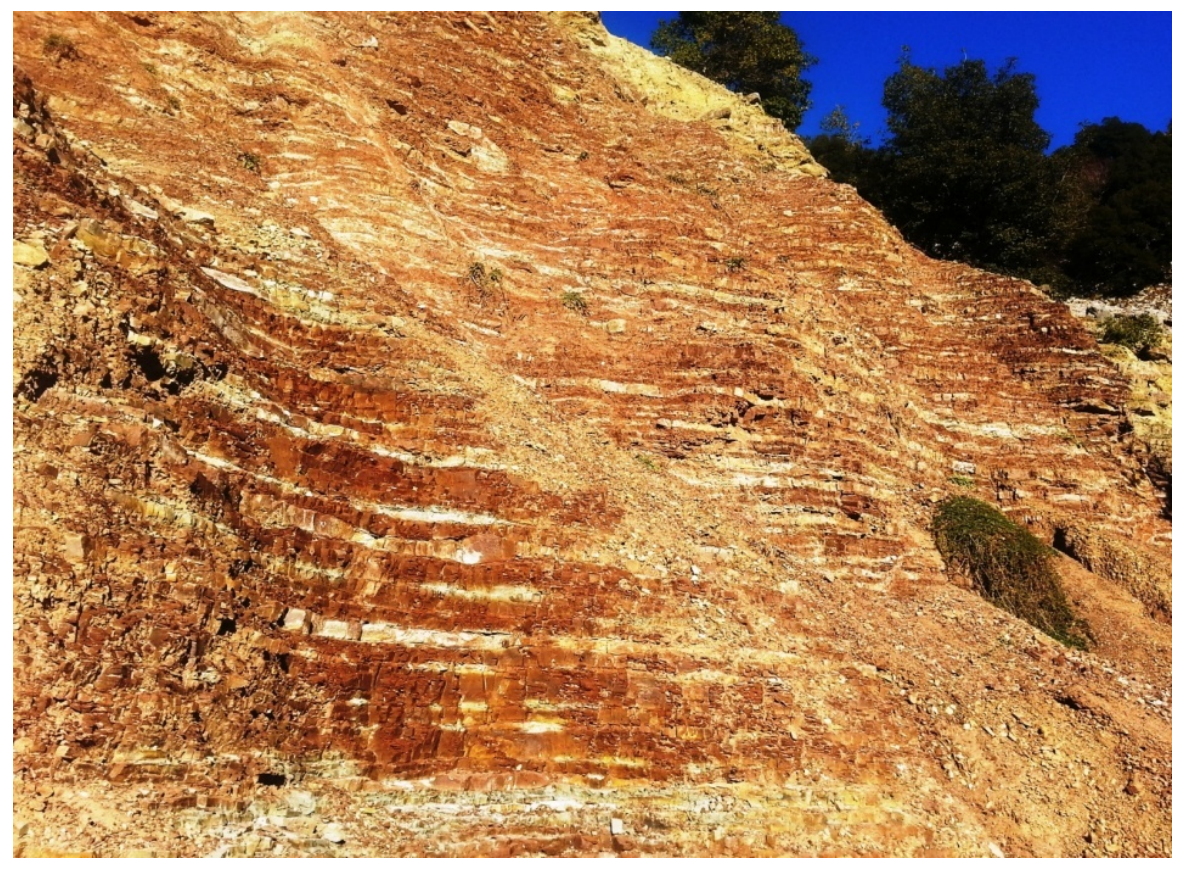

Figure 9. Platy limestones with cherts of the Pindos Zone as occur at Mount Lakmos. 


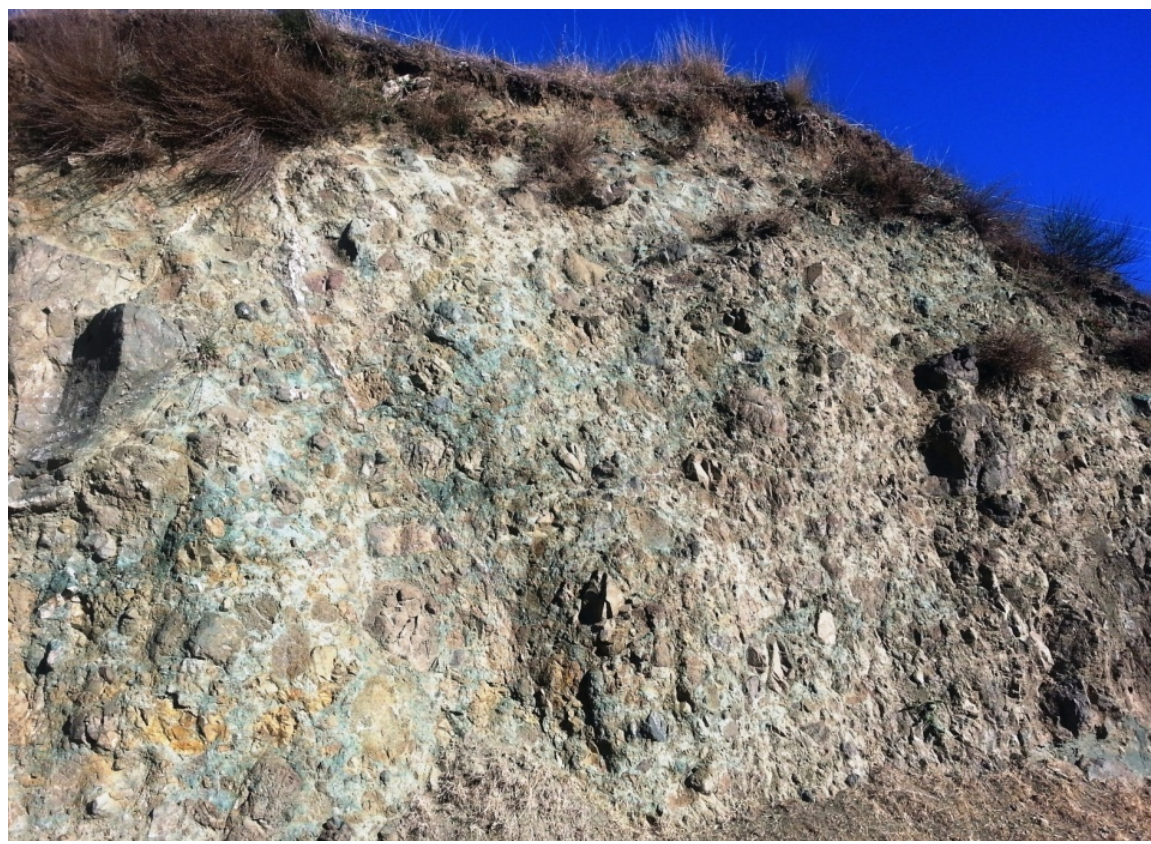

Figure 10. A series of transition beds towards the second flysch of the Pindos Zone in Megalo Peristeri area.

typical and representative flysch of the Greek territory. In the clayey-sandstone sediments, olistholiths are often observed with dimensions ranging from a few $\mathrm{cm}$ to many meters. These olistholiths are originated from the sandstone rocks of this flysch and have slid into its argillaceous parts. In addition, they are intensely fractured. The total process of the sedimentation and tectonics in the area resulted in the occurrence of the above-mentioned formation as a chaotic mixture and created a formation called internationally as wildflysch. In many locations, the flysch of the Pindos Zone has been intensely folded (Figure 11) and the Oligocene molassic sediments of the Mesohellenic Trough have overlain unconformably these folds [16] [96].

Ophiolitic masses have been placed tectonically on the flysch of the Pindos Zone. These masses constitute a complicated petrological and geological unit which is extended widely in the mountainous area among Metsovo, Panagia, Vovoussa, Abdela, Samarina and Smolikas Mountain. The tectonic nappe in the areas of Grammos Mountain and Amarantos Konitsa occupies a smaller extent. These ophiolites have not originated from the Pindos Zone since they don't occur within the overthrust sheets of the Pindos Zone. So, it is suggested that they have come from the Subpelagonian Zone and their tectonic contact with the Tertiary flysch has been observed. This complicated tectonic nappe consists of (from top to base):

(a) Transgressive series of the Subpelagonian Zone composed of clastic, brecciated, medium to thick-bedded limestones with Rudists,

(b) Ophiolitic complex consisting of ultabasic and basic rocks as peridotites, pyroxenites, gabbros, harzburgites, dunites, dolerites, diabases, spilites, diorites, basalts, serpentinites, pillow lavas, and amphibolites, and 


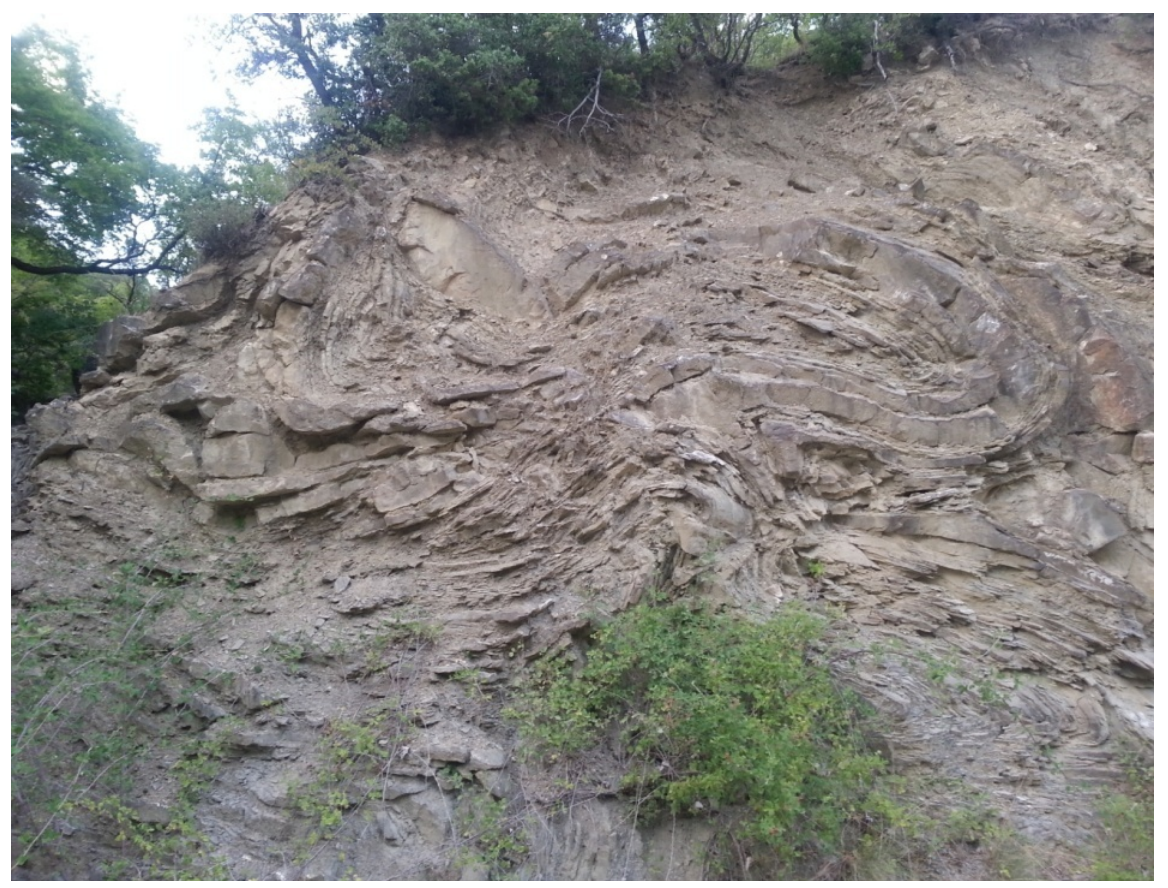

Figure 11. Intensely folded flysch of the Pindos Zone near the village of Nikanor.

(c) The mixture formation-mélange composed of fragments from Middle Triassic and Upper Jurassic lavas, cherts, serpentinites, clastic volcanics, limestones and gabbro which are enclosed as olistholiths or tectonic inclusions in the cement of siltstone composition [102].

The mélange and carbonate formations of this trangressive series accompany the ophiolites [90]. It is suggested that the ophiolitic masses have been overthrusted on the flysch of Pindos Zone during the final Tertiary folding stage after the flysch sedimentation [98]. These overthrusts resulted in the intense tectonism of the ophiolites and the strong tectonic mixing of the various rocks of the ophiolitic complex, while mylonitized zones and tectonic breccias are observed in many areas (p.e. Distrato).

\subsection{Gavrovo Zone}

The Gavrovo Zone is located between the Pindos Zone and the Ionian one (Figure 1(a)). It is extended in a NNW-SSE direction and it has a limited exposure (5.6\%). In the northern part of Epirus, the tectonic nappe of the Pindos Zone is overthrusted on the Ionian Zone, covering fully the Gavrovo Zone. In this area, the Gavrozo zone occurs only as tectonic window [89]. In Epirus, this zone occurs at Valtos Mountains.

The Gavrozo Zone characterized by continuous neritic carbonate sedimentation, without clayey or siliceous layers, during Triassic-Upper Eocene (Figure 12). The carbonate sediments were deposited on the margins of the Apulian Plate and their total thickness is about $1800 \mathrm{~m}$. The Gavrovo Zone is made up of the following lithological formations [18] [99]:

(a) Limestones of Cretaceous (Senonian-Maestrichtian) age (G.JC-kd). They 

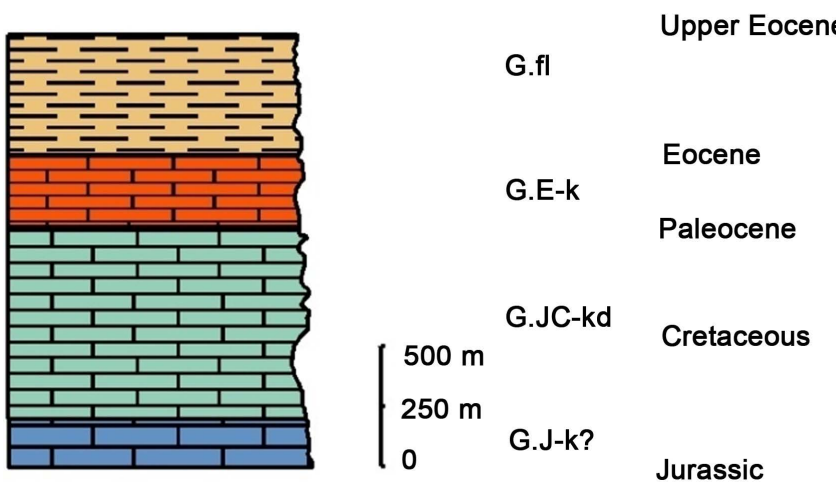

Figure 12. Lithostratigraphic column of the Gavrovo Zone, illustrating the geological formations that crop out in the study area and are presented in the Geological map on Figure 2: G.fl-Flysch, G.fl-s-Flysch-mainly Sandstones, G.E-k-Paleocene-Eocene Limestones, G.JC-kd-Cretaceous Limestones, G.J-k-Jurassic Limestones (not appeared on map).

constitute clastic, light-coloured to grey, compact, bioclastic, locally dolomitized limestones with numerous fragments of Rudists in the upper part.

(b) Limestones of Paleocene-Eocene age (G.E-k). These carbonate formations are described as black, micritic, platy and locally bioclastic and brecciated limestones.

(c) Flysch of Upper Eocene (Priabonian)-Late Oligocene age (G.ff). The lower members consist of coarse to fine-grained and platy sandstones- $G . f l-s$ with a few layers/alternations of clayey marls and small lenticular intercalations of conglomerates. The thickness of the sandstone beds reaches $3 \mathrm{~m}$ and it reduces gradually upwards. In the upper part, silty and clayey marls domimate. Sandstone layers and conglomerates of sandstone and calcareous cobbles occur in these marly beds. This flysch is differentiated lithologically from the flysch formations of the Pindos and Ionian Zones. Its main feature is the significant presence of conglomerates which often form banks having thickness more than $2 \mathrm{~m}$. In addition, semi-rounded or well-rounded calcareous or cherty cobbles and gravels are observed in the siltstone mass [69] [71]. Finally, the rocks of the Gavrovo Zone were affected by mild orogenic tectonism [97] [99], which took place during Tertiary resulted in folding the formations with push westward, simultaneously with the overthrust of the Pindos Zone. In Epirus, a large anticlinic structure has been formed plunging towards northwestern and was affected by the activity of large normal faults in NW-SE and NE-SW general directions.

\subsection{Ionian Zone}

The Ionian Zone occupies the largest part (78\%) of Epirus (western part) extended in NW-SE direction between the Zones of Gavrovo and Pindos (Figure 1(a)). The Ionian Zone belongs to External Hellenides constituting part of the wider branch Hellenides-Dinarides-Apennina which delineated the Apoulia (Peri-Adriatic) Plate [103] [104]. The Ionian Zone is made up of Alpine formations, white the existence of a pre-alpine basement has not been proven. In general, this Zone consists of the following geological formations [20]: evaporites with 
gypsum and Triassic breccias, limestones, and flysch (Figure 3).

The oldest carbonate rocks, deposited on the Triassic evaporites, are the neritic Upper Triassiclimestones(Foustapidima)-I.T-k consisting of (a) black sublithographic limestones containing fossils, (b) light-coloured, intensely tectonized dolomites without fossils, (c) calcareous breccias, and (d) marly limestones [89] [90].

Triassic evaporites and breccias associated with them constitute the base of the Ionian Zone (Figure 13). They consist of gypsum, salt, grey-black carbonate breccias (known as Triassic breccias), fragments of sublithographic limestones, and black clayey horizons. Gypsum-I.T-g and Triassic breccias-I.T-br occur at surface in some locations. Dolomites are intercalated in the gypsum. Based on the study of Foraminifera included in these dolomites, it has proven that gypsum is of Lower-Middle Triassic age [24] [105]. There is no surface manifestation of the salt. Salt has been found by boreholes at various sites, as for example in Monolithi Ioannina (northeastern of Arta) [106] and Filiates [20]. Except for the original stratigraphic position, the evaporites are often found within younger rocks of the Ionian Zone due to diapirism and their movement through faults. Primarily, the Triassic evaporites of the Ionian Zone were fractured and moved (horizontally and vertically) mainly during the orogenesis of Pindos and they are re-activated during Neogene and Quaternary providing neo-diapirisms in the corresponding sediments. The movement of the evaporites (palaeodiapirisms and neodiapiris [56] [107] $\mathrm{ms}$ ) contributed to the geomorphological characterristics and the tectonic evolution of the area. The Triassic evaporites, which had been risen to the surface in various areas, were exposed to the erosion resulted in the removal of easy soluble salts $(\mathrm{NaCl}, \mathrm{KCl})$ by the influence of meteoric waters,

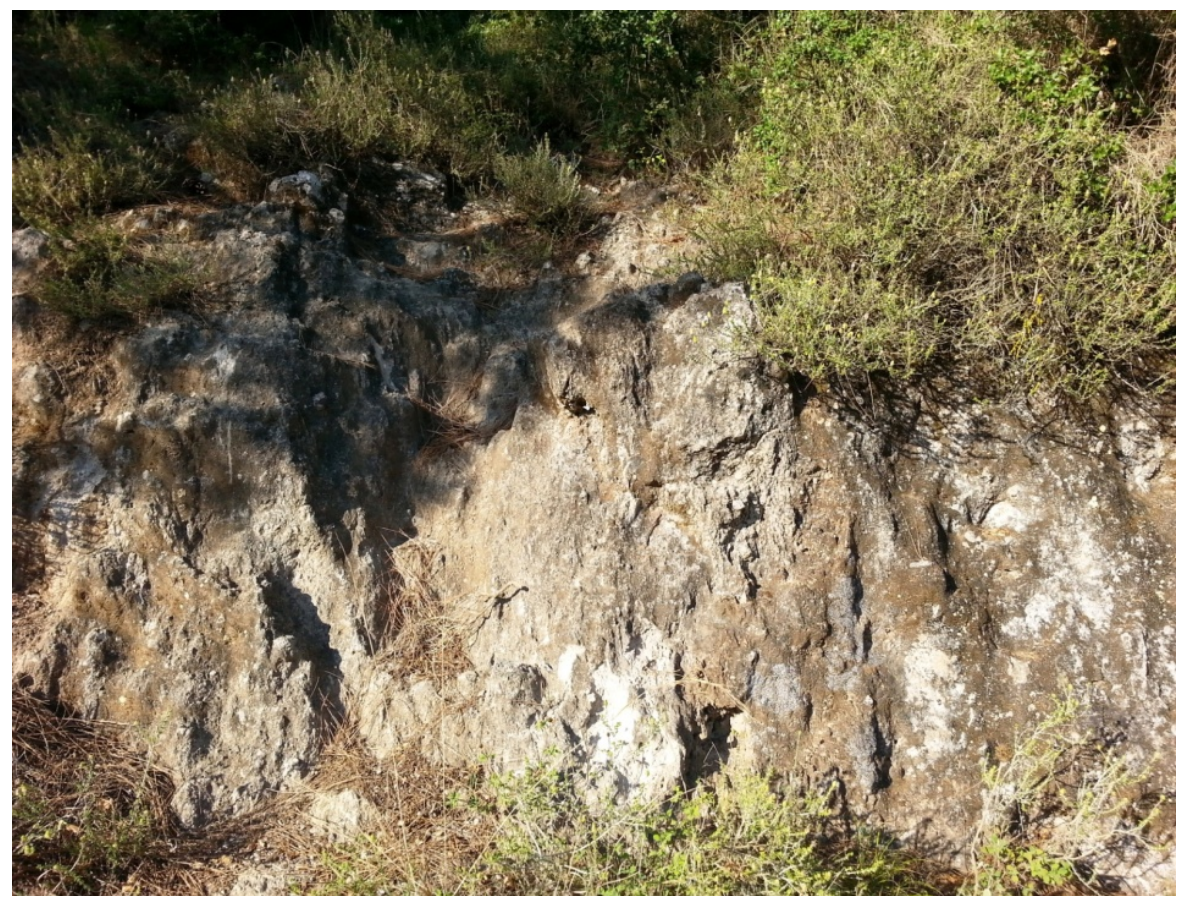

Figure 13. Occurrence of Triaccic breccias in the Filiates area. 
the wetting of the remaining anhydrite and its change to gypsum [56]. By this way, the occurrences of gypsum and the absence of salts at surface can be explained. Despite the thickness of the primary evaporitic series is suggested to be greater than $1000 \mathrm{~m}$, its real thickness reaches $3500 \mathrm{~m}$ due to diapirism [20] [73] [75], according to the results from deep oil exploration boreholes (e.g. Filiates-1) [75].

Next formation is the neritic Pantokratoras limestones, of Lower Jurassic age (Lower-Middle Lias). They consist of massive and compact limestones (Figure 4). Alternations or lateral transitions of limestones with algae and organogenic limestones indicate sedimentation in a paleo-environment of very shallow plat form [20] [40] [48] [49]. Fossils as algae, brachiopods, lamellibranches and foraminifera occur in this formation. The thickness of the Pantokratoras limestones exceeds $1000 \mathrm{~m}$ [20] and it may reach $1500 \mathrm{~m}$ [90]. This significant thickness can be considered as the result of rapid subsiding of the platform compensated by rapid sedimentation, so that the platform remained shallow during the sedimentation. During Upper Lias, two series of carbonate rocks were deposited: Louros limestones and Siniae limestones. Both series are suggested to be coeval with and laterally equivalent to probable lateral transitions [44] [45] [46] [48] [68]. Their formation phase marked the subsiding of the area due to the activity of the marginal normal faults as well as the creation of the semipelagic Ionian basin and its differentiation from ridges of Gavrovo (east) and Apulian (west). The Louros limestones, 60 - $70 \mathrm{~m}$ thick, are composed of micritic limestones with Ammonites, Brachiopods, and Foraminifera and paleogeographically are set at the marginal areas of the Ionian basin. The Siniae limestones reaching $150 \mathrm{~m}$ in thickness consist of sublithographic limestones with Radiolaria and Ammonites (in their upper part) and infrequent intercalations of cherts [48] [108]. It is noted that the 1:50,000 scale sheets of the geological map for Epirus and the abovementioned three carbonate formations (Pantokratoras limestones, Louros limestones and Siniae limestones) have been mapped as a single formation I.TJ-kd [68] [72]-[83] [88].

Next formations of the Ionian Zone are the Ammonitico Rosso-I.J-kd (limestones) and the lateral equivalent Posidonia Bed-IJ-sh (shales with Posidonia) of Middle Jurassic age (Upper Lias-Dogger-Lower Malm or Toarcian-Aalenian) [18] [20] [48], 50 - $200 \mathrm{~m}$ thick (Figure 14). Red-violet Ammonitico Rosso consist of marly and brecciated layers (blue marls with intercalations of breccias) in the lower parts and red nodular limestones with marly intercalations in the upper parts. These limestones were deposited on the sides on the Ionian basin. The lower shales with Posidonia (Posidonia beds) are composed of thin-bedded marly limestones and marls in the lower part and argillaceous-argillosiliceous sediments rich in Radiolaria and Posidonia in the upper part [20] [89] [109], while in some locations and where the formation has a significant thickness, cobble-breccia layers with the presence of petrified branches and conifer leaves in some sites [110]. The Ammonitico Rosso and Posidonia beds represent the deposition of hemipelagic-pelagic sediments in an environment with individual, more or less 


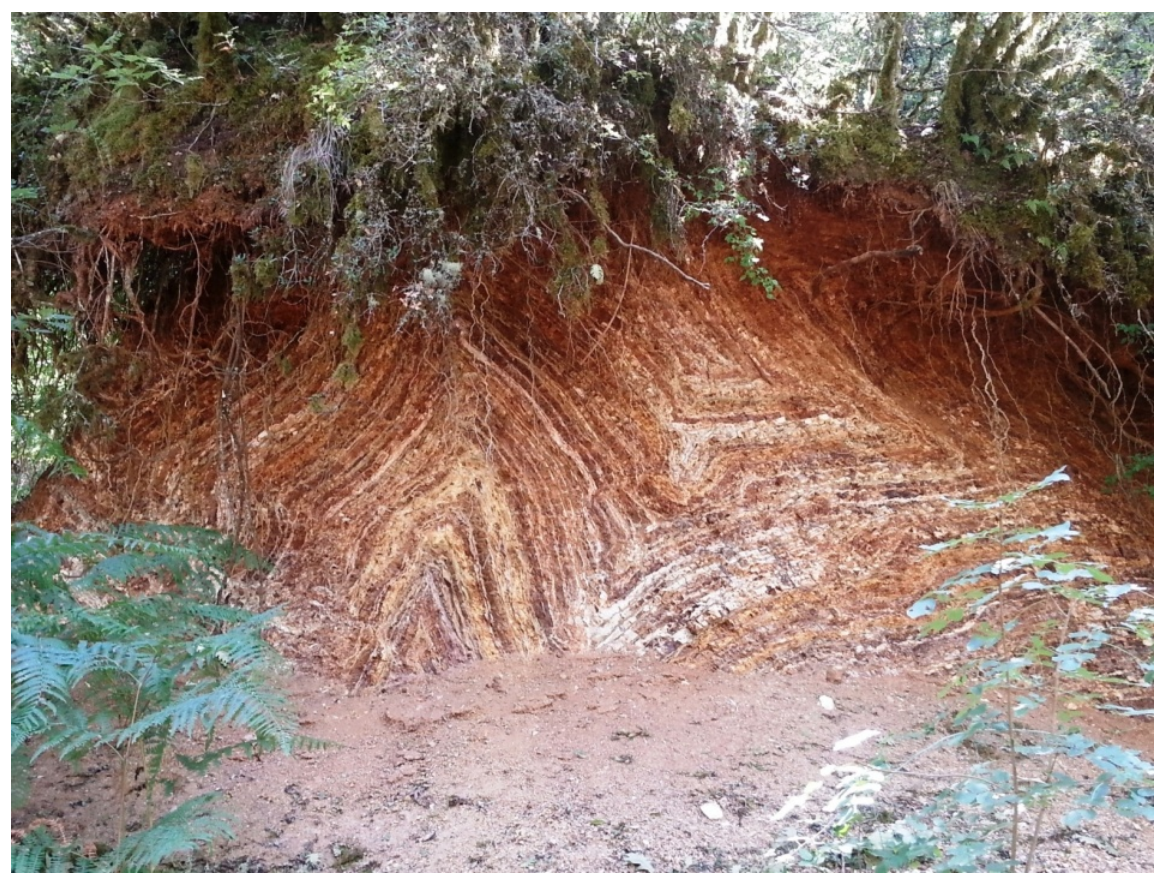

Figure 14. Multi-foldedshales with Posidonia as occur in Dhelvinakopouloarea.

deep subbasins.

The next lithostratigraphic formation is limestones with filaments-I.J-kd, of Middle Jurassic (Bajosian-Callovian) or locally Middle Bathonian age [48] [111], having a maximum thickness of $50 \mathrm{~m}$. They are composed of alterations of pelagic limestones with cherts. The pelagic limestones are sub-lithographic, nodular (in the lower parts) and brecciated and contain Lamellibranches, Radiolaria and rarely Ammonites.

The upper/siliceous shales with Posidonia-I.J-sh, known as Radiolarites [111], of Upper Jurassic (Oxfordian-Tithonian) age follow [112] [113]. They consist of alterations of clayey-siliceous layers with cherts and are rich in Radiolaria [48]. In some areas, this formation includes calcareous intercalations. The thickness is estimated to be about $50 \mathrm{~m}$. The main lithological difference between these shales with the above-mentioned lower Posidonia beds is their high silica content.

The distribution of the syn-rift formations of Ammonitico Rosso, Posidonia beds (Shales with Posidonia), limestones with filaments and upper Shales with Posidonia in combination with other tectonic or stratigraphic data show that their deposition took place in different subbasins (semi-trenches) resulted from the internal differentiation of the Ionian Zone. The extensional tectonic activity in combination with the salt movement (halokinesis of evaporites) caused this differentiation [48] [49]. In the deeper parts of the subbasins, the full sequence consisting of lower shales with Posidonia, Ammonitico Rosso, limestones with filaments, upper shales with Posidonia was deposited with transition to no full sequences and gradual decrease in their thickness (until full stratigraphic pinching-out in relatively shallow or almost emerging areas). In areas which corresponded to submarine ridges, Lower-Middle Jurassic (Toarsian-Callovian) phosphorite zones occur [114]. The upper shales with Posidonia, in contrast with the 
underlying formations, are presented throughout the Ionian Zone indicating that during their deposition the submarine topographical differences were mitigated tending to be eliminated [48] [49]. The transition to the siliceous formations of the upper shales with Posidonia is considered to be related to the bathymetry of the subbasins and the Calcite Compensation Depth-CCD. Therefore, the sea level rise and the increase of CCD level, due to relative lack of organisms rich in calcite material, can explain the siliceous sedimentation represented by them.

Following the upper siliceous shales with Posidonia, the next formation is the pelagic Vigla limestones-I.C- $k d$ of Lower-Upper Cretaceous (Berriasian-Lower Senonian) age [48] [58] [59] [115] [116] (Figure 15). It is considered to be the first post-rift formation of the Ionian Zone. It consists of platy, thin-bedded, sub-lithographical limestones of a white or grey colour, with chert intercalations (0.5 - $4 \mathrm{~cm}$ thick), lenses and nodules as well as intercalations of white-yellow clays. Towards the upper part of the formation, the upper siliceous series of Vigla or Vigla shales of Upper Cretaceous age (Cenomanian-Turonian) occur. In this series, the siliceous intercalations alternate with clayey-marly layers [48]. At the eastern margin of the Ionian Zone and more specifically in the mountainous areas of Xirovounio and Gamila, the thick grey Vigla limestone formation becomes dolomitic, bituminous and thick-bedded in its lower parts and thin-bedded with clayey intercalations and black cherts in its upper ones [68] [80] [87]. The calcareous sedimentation was mainly due to the reduction of the CCD level. Concerning with the pre-mentioned Vigla shales of mainly siliceous composition, their deposition is attributed to the sea level rise [27]. In the Central Ionian Zone, towards its eastern margin and over upper the siliceous series of Vigla and in anticlinic areas, an Upper Cretaceous (Lower Sennonian) phos phate horizon occurs

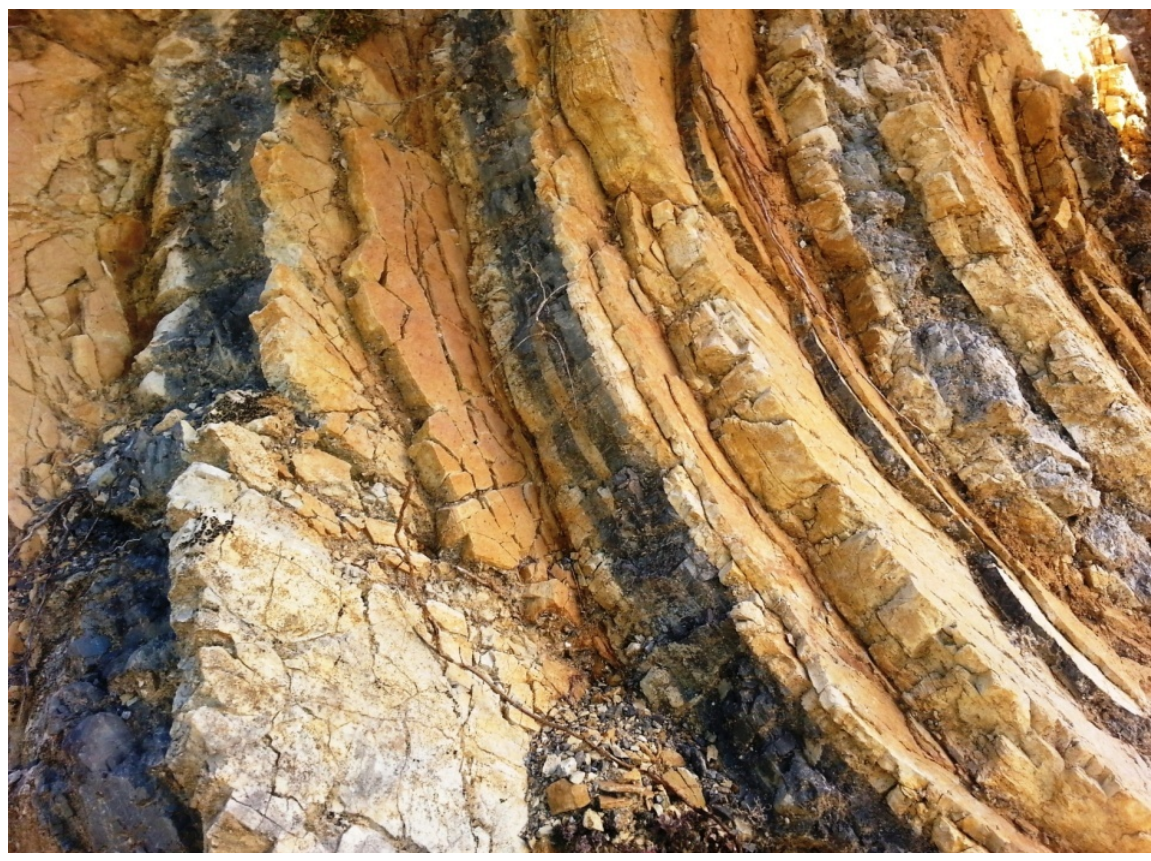

Figure 15. Folded Vigla limestones near the town of Ioannina. 
often [114] [117] [118]. The thickness of the Vigla limestones is $700-900 \mathrm{~m}$ in the Internal and External Zone and smaller $(100-500 \mathrm{~m})$ in the Central Zone [67] [68] [71] [83] [85] [87] [88]. This differentiation and range of thickness may be attributed to halokinesis, i.e. salt movement [48] [49].

The next post-rift formation is the Upper Sennonian limestones-I.C- $k$ dated by the presence of Foraminifera Globotruncanids [58] (Figure 16). This formation consists of pelagic micritic sub-lithographic limestones alternating with thick-bedded brecciated limestones containing Rudist fragments. The main characteristic is their frequent occurrence as thick banks in the field. The clastic material occurs at relatively high percentage in the Internal and External Ionian Zone and is reduced in the Central one. The thickness of the Upper Sennonian limestones ranges from 50 to $300 \mathrm{~m}$ [67] [68] [69] [71]-[83] [85] [87] [88].

The pelagic Paleocene-Eocene limestones-I.E-kfollow and their age has been determined by the presence of abundant Foraminifera [20]. They are composed of white, well-bedded, compact; thin to medium-platy micritic limestones with rare chert intercalations and more rarely horizons of microbrecciated limestones in some places.

The youngest formation of the Ionian Zone is flysch-I.fl of Upper Eocene-Lower Miocene (Aquitanian-Burdigalian) age when the folding of this Zone took place (Figure 17). Its upper limit varies between end of the Oligocene in the Internal Ionian Zone and Burdigalian in the External Ionian Zone [20] [119]. The flysch has a psammitic-marly composition in the lower layers and consists of alternations of siltstones, marls, marly limestones, sandy clays, clays, sandstones and rarely conglomerates towards its upper parts. From east to west, an increase in the ratio of fine-grained sediments (clay intercalations) to coarse-grained ones(sandstones) is observed [42]. This flysch can be distinguished into three additional types de-

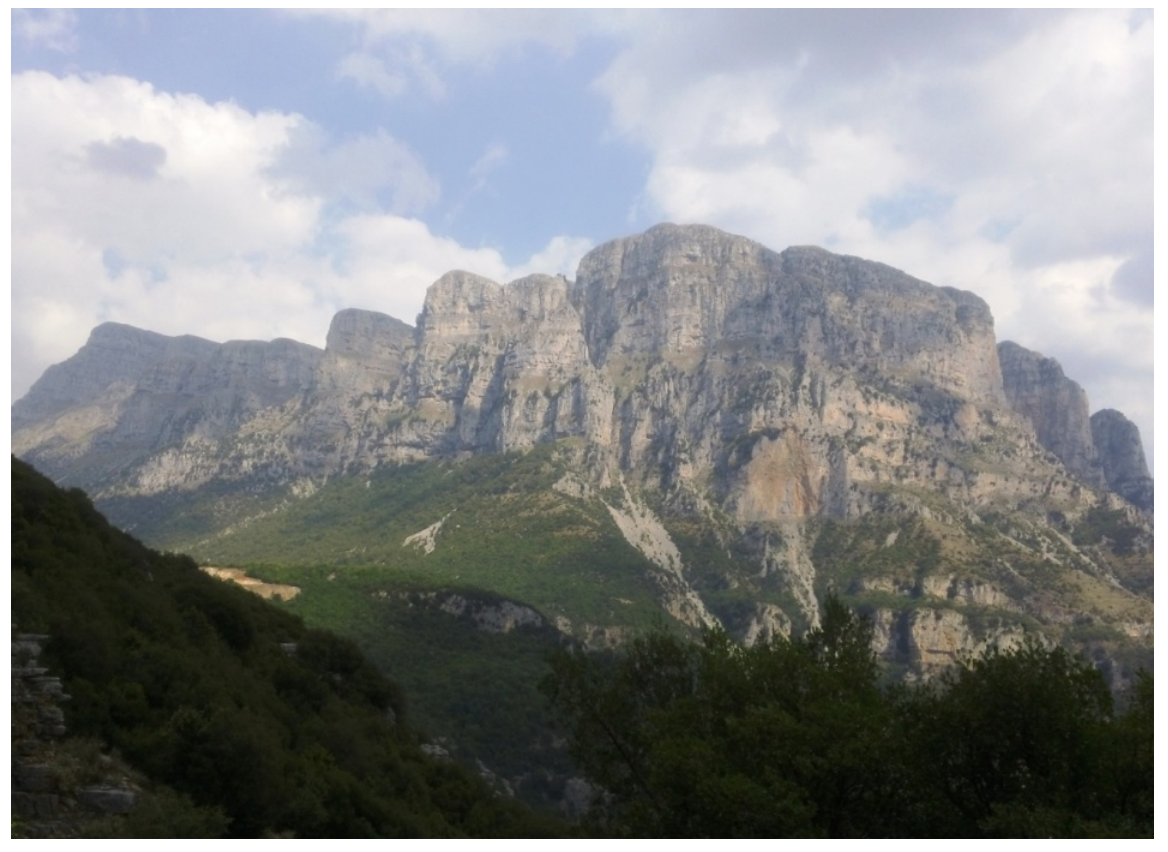

Figure 16. Platy Upper Sennonian limestones as occur at Mount Asfakas (Towers; village Small Papigko). 


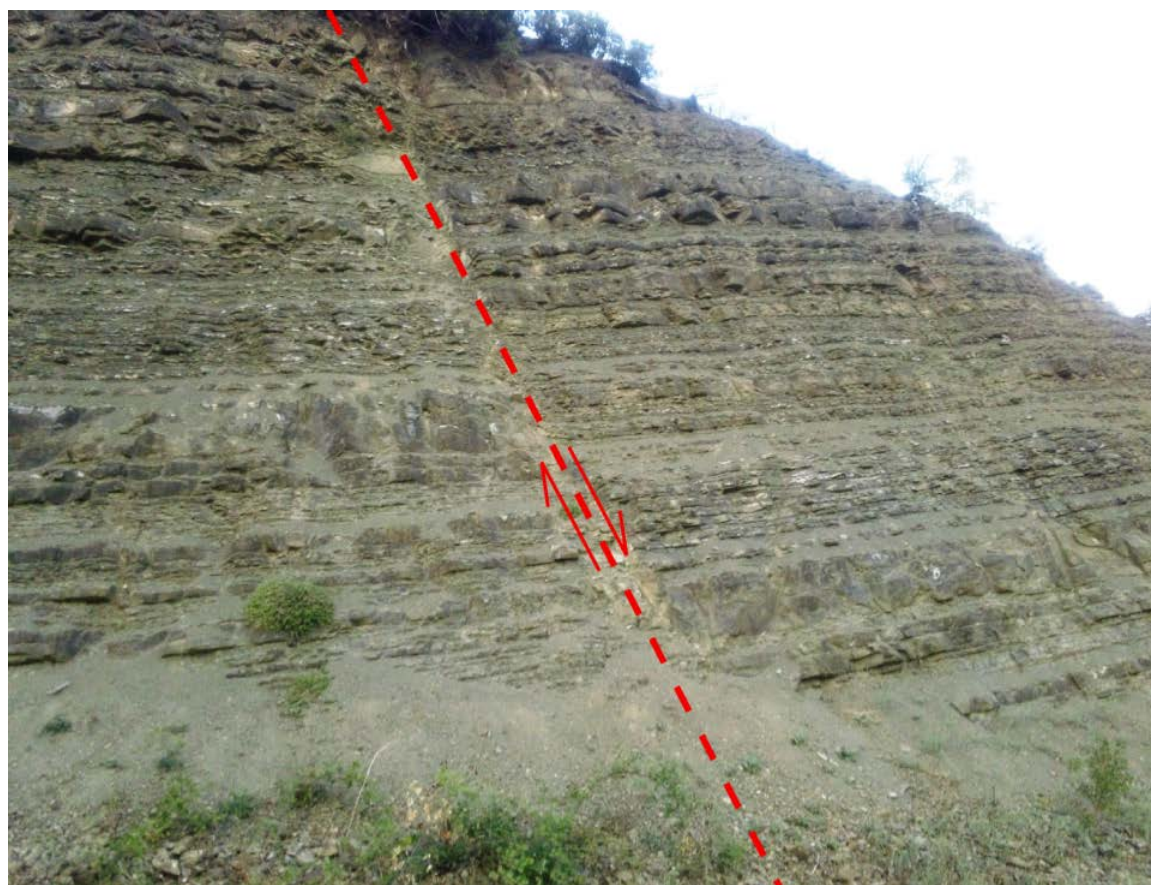

Figure 17. A section near the village of Lavdani showing the flysch of the Ionian Zone affected by an oblique-slip fault (with red line marked the trace of fault).

pending on the percentage of the predominant materials; i.e. marls (I.fl-m), sandstones $(I . f l-s)$ and conglomerates $(I . f f-c)$, as shown in the map of Figure 2. In addition, during Oligocene, transitional beds (very thin layers of white-grey marly limestones and siltstones with intercalations of compact enough horizons of coarse-grained sandstones) are ascertained showing a short and gradual transition to the calcareous phase of the clastic sedimentation of flysch. The thickness of this flysch exceeds $1000 \mathrm{~m}$ and varies from place to place [65] [67] [68] [69] [71]-[83] [85] [87] [88]. The folded flysch influences its apparent thickness. The greatest thicknesses are observed in the Voutsara basin (Zallogo-Voutsara syncline in Central Ionian Zone) reaching $2500 \mathrm{~m}$ (Burdigalian formation included) and Petas-Arachthos syncline exceeding $2000 \mathrm{~m}$. The thickness is reduced westwards, where it reaches $1500-2000 \mathrm{~m}$ [69] [77].

During Burdigalian (Lower Miocene), the deposition of marine molasse sediments consisting of blue marls $(\mathrm{Ne})$ with banks of psammitic organic limestone took place. The deposition of younger molasse sediments was continued in Middle Miocene and then, during the emergence-orogenesis of the Ionian Zone (from east to west). The molasse sediments were deposited on the western margins of the elevated parts [60].

The stratigraghy of the Ionian Zone is related closely to its evolution from carbonate platform to pelagic sedimentation basin, which began in Middle Lias (Lower Jurassic). The formations, which deposited before the differentiation of Zone as basin between the Gavrovo and Paxoi Zones, constitute the pre-rift formations [48]. Initially, the Ionian Zone was an integral part of the single platform composed of the Apulian, Paxoi, Ionian, and Gavrovo Zones with rifting during 
Upper Carboniferous-Lower Triassic [104] [120] and deposition of evaporites and neritic limestones until Sinemurian (Lower Jurassic[49] [108]). During the second stage, the Ionian Zone acted as pelagic sedimentation basin bounded by the ridges of Apulian (west) and Gavrovo (east) [21] [48]. This stage began following the end of rifting and the beginning of the Tethys ocean opening during Middle Lias (Lower Jurassic) [46] [108] [120]. The beginning of the post-rifting period has been determined between Tithonian (Upper Jurassic) and Cretaceous with the beginning of the deposition of the pelagic Vigla limestones throughout the area of the Ionian basin. The pelagic conditions (pelagic sedimentation with clastic interbeds of neighbouring platforms of Gavrovo and Apulian) were maintained until the end of the Eocene, when the flysch deposition began [48] [49].

\section{Discussion and Conclusions}

The resulting picture of the geological and tectonic structure of northwestern Greece (Epirus) is summarized in the new Geological Map of Figure 2 and the lithostratigraphic columns (Figure 3, Figure 8 and Figure 12) are produced within the scope of the present paper. More specifically, Epirus is made up of geological formations belonging to the Subpelagonian, Pindos, Gavrovo and Ionian Geotectonic Zones of Hellenides, while post-alpine (Upper Eocene-Quaternary) sediments have been deposited on the rocks of these zones. These geological formations were grouped on the basis of their distinctive features, while their detailed description was based on previous studies as well as personal observations and measurements in the field. The sheer number of geological formations often makes it difficult to study a greater area as a whole, which is the case of the present study area, extending over $100 \times 150 \mathrm{~km}$. Furthermore, the lithostratigraphic columns of the geotectonic structure of Epirus (Figure 3, Figure 8 and Figure 12) were produced by taking into account the actual thickness of the new grouped formations encountered in each geotectonic zone. In this manner, one may easily observe the thickness of each formation, e.g. how the flysch thickness varies across the geotectonic zones of northwestern Greece.

The geopolitical location of Epirus, along with the elements of economic interest encountered in the area, such as the oil deposits which are detected at various locations by the scientific teams of IGRS-IFP [20] and B.P. Co [22], calls for the elaboration of new, revised maps of improved accuracy, using the new available technologies. The combined data, produced by the work of numerous researchers since the 1840 's, can complete the puzzle that is the geological structure of northwestern Greece.

Taking into account the views mentioned by various researchers and the field work data, a short presentation of geological structure and tectonic conditions for each zone follows.

The Subpelagonian Zone, located east of the Pindos Zone and west of Pelagonian Zone, constitutes a small part in the northeastern part of Epirus and consists of ophiolites with deep marine sediments (schist-chert formation) deposited either on carbonate rocks or not. In the area of the Subpelagonian Zone, the $\mathrm{Me}$ - 
sohellenic Trough was developed during Oligocene-Middle Miocene filled with post-alpine molassic sediments.

The Pindos Zone, of Upper Triassic-Upper Eocene age, is extended in a general N-S direction as a tectonic nappe. It consists of Paleocene-Eocene flysch, alternations of platy limestones with sandstones and argillites of Late Cretaceous age (transition zone), Upper Cretaceous pelagic platy limestones with siliceous intercalations, Lower Cretaceous flysch-first flysch, Jurassic schist-chert formation, Upper Triassic platy to thin-platy limestones and clastic formation of Triassic age. The Pindos Zone constitutes a tectonic nappe overthrusted on the Ionian Zone. The tectonic individual overthrust sheets are overthrusted onto each other from east to west and their axes are oriented in directions ranging from N-S to NNW-SSE. Characteristic tectonic structures constitute the Athamanian Mounts (Tzoumerka) and Mt. Lakmos.

The Gavrovo Zone, of Triassic-Oligocene age, is located west of the Pindos Zone. It occurs in the southeastern part of Epirus, in the area of Valtos Mountains. It consists of the following geological formations: Upper Eocene-Oligocene flysch, Jurassic-Upper Eocene neritic limestones rich in fossils (Eocene carbonate series, Cretaceous limestones) and Upper Triassic dolomites. Totally, the Gavrovo Zone constitutes an anticlinical structure having an axis of NNW-SSE direction and it is characterized by heavy type tectonics.

The Ionian Zone, of Triassic-Lower Miocene age, oriented in N-S direction occupies the largest part of Epirus. It extends west of the Gavrovo Zone and consists of the following geological formations: Late Eocene-Lower Miocene flysch, Paleocene-Eocene semi-pelagic platy limestones, Upper Senonian limestones, Upper Jurassic-Upper Cretaceous platy limestones rich in radiolaria alternating with siliceous and chert series (Vigla limestones), limestones rich in Filaments, shales with Posidonia and Ammonitico Rosso of Middle-Upper Jurassic age, Lower Jurassic Siniae and Louros limestones, calcareous breccias and Upper Triassiclimestones of Upper Triassic age and Triassic evaporites (gypsum and salt). Mio-Pliocene sediments and alluvial deposits have been deposited over the Late Eocene-Lower Miocene flysch. The tectonic setting of the Ionian Zone is characterized by a series of parallel mega-synclines or mega-anticlines, thrusted or overthrusted onto each other westward. Their axes are generally oriented in a NW-SE direction, while southwards their directions are changed ranging from NNW-SSE and NNE-SSW intersected by E-W strike-slip faults.

Based on the lithology and types of rocks for each geotectonic zone, the geological structure of northwestern Greece consists of the following main-indepen-dently of zones-geological formations:

- Ophiolites of Jurassic age,

- Limestones, dolomites, and schist-cherts of Mesozoic age,

- Flysch of Upper Cretaceous age,

- Limestones of Paleocene-Burdigalian age,

- Flysch of Maestrichtian-Aquitanian age,

- Brackish Neogene sediments of Miocene-Paleocene age, and

- Quaternary deposits (scree, coastal conglomerates, fluvial deposits etc). 
Summarizing the study-assessment of the Map of Figure 2 and the distribution of these major formations in northwestern Greece, leads to the initial observation that limestones dominate the western part and areas of higher elevation. Flysch formations occur in the eastern part and lower altitude areas. Moreover, the formations' boundaries have been corrected-revised, as a result of field mapping. Certain typical examples of such modifications are listed hereunder:

(a) The area of the Subpelagonian and Pindos Zones, where the ophiolite and flysch formations are encountered, whose locations are largely inconsistent with the respective locations derived from the mapping of the Metsovo and Pentalofo sheets of the Geological Map of Greece, of the Institute of Geology and Mineral Exploration-IGME by Brunn [65] [66], and

(b) All the areas of the map, are covered by Neogene and Quaternary deposits. Such deposits are of particular interest, because based on their stratigraphic succession, one can evaluate the neotectonic activity of area.

It is worth mentioning that the field works particularly focused on the detection and identification of tectonic elements, contribute to the completeness and accuracy of a geological map. These elements are the product of systematic study and observation, evaluation of fault activity, and detailed geologicaltectonic mapping. According to the international classification of faults, they were classified as active, potentially active and non active. All this data are completely new, presented here for the first time and it provides useful information on the area's degree of activity and the potential occurrence of earthquakes, thus, leading to the better perception of a region's neotectonic evolution.

The knowledge of the geological structure constitutes the cornerstone for further research, as it results in understanding of the relief and drainage network evolution. Plenty of scientific works combine their data with the geological structure. The existing geological data may be changed due to field observations in the frame of a detailed geological study. Field works can modify the bibliographic references to a dynamic tool resulting in updated or new conclusions about the geological setting and the geotectonic structure of a study area combining new with old data. Despite a large number of scientists have studied an area, there are undiscovered and unknown elements well hidden by the geological time.

\section{References}

[1] Ntokos, D. (2017) Neotectonic-Geomorphological Study of Epirus, Northwestern Greece and Compiling of Neotectonic Map, by Use of Geographic Information Systems. PhD Thesis, National Technical University of Athens, Athens, 407.

[2] Boue, A. (1840) La Tourqie d' Europe. Paris.

[3] Viquesnel, A. (1868) Voyage dans la Turquie d'Europe. Paris, 134.

[4] Neumayr, M. (1880) Der geologische Bau des westlichen Mittelgricchenland: Denschriften der Osterreichischen Akademie der Wissenschaften Mathemaiisch-Naturwisscnschaftlicht Klasst, 40, 91-128.

[5] Philippson, A. (1889) Das Erdbeben in Griechenland am 25 August 1889. Gotha, 35, 290-291. 
[6] Philippson, A. (1892) Der Peloponnes Versuch eine Landeskunde auf geologischer Grundlage. Friedlander, Berlin.

[7] Philippson, A. (1893) Die Erbeben von Zante. Gotha, 39, 215-218.

[8] Philippson, A. (1895) Beisen und Forschungen im Nord Griechenland, Zeit. Ges. Erdk., 30, 135-226.

[9] Philippson, A. (1898) La tectonique de I' Egeide. Annales de Geographie Paris, 7, 112-141. https://doi.org/10.3406/geo.1898.18101

[10] Renz, C. (1910) Die Geologie Griechenlands. I. Teil. Stratigraphische Untersuchungen im griechischen Mesozoikum und Palaözoikum. Jb. K.-Kg. Geol. Reichsanst. Wien 60, 421-636.

[11] Renz, C. (1928) Geologische Untersuchungen im aetolischen Pindow. Bulletin of Academy of Athens, 13, 664-677.

[12] Renz, C. (1932) The Acarnanian coastal islet of Kalamos. Memoires of the Geological Survey of Greece, 2, 32, Athens.

[13] Renz, C. (1940) Tectonic der Griechischen gebige. Prak. Akad. Athinon, 8, 171.

[14] Renz, C. (1947) Progress of the Geological Exploration of Greece. American Journal of Science, 245, 175-180. https://doi.org/10.2475/ajs.245.3.175

[15] Renz, C. (1955) Die vorneogene stratigraphie der normal-sedimentaren formationen Griechenlands: Institute of Geological Subsurface Research, Athens, 637.

[16] Brunn, J. (1956) Contribution à l'étude du Pinde septentrional et d'une partie de la Macédoine occidentale. Annales Géologiques du Pays Helléniques, 7, 358.

[17] Aubouin, J. (1957) Essai de correlation stratigrapbique de la Grece occidentale. Bulletin de la Societe Geologique de France, 7, 281-304.

[18] Aubouin, J. (1959) Contribution à l' étude géologique de la Grèce septentrionale: Le confins de l' Epire et de la Thessalie. Annales Géologiques des Pays Helléniques, 10, 525.

[19] Aubouin, J. (1973) Des tectoniques superposees et de leur signification par rapport aux modeles geophysiques: L' example des Dinarides; paleotectonique, tarditectonique neotectonique. Bulletin de la Société Géologique de France, 5-6, 426-460. https://doi.org/10.2113/gssgfbull.S7-XV.5-6.426

[20] IGRS-IFP (1966) Etude geologique de l'Epire (Grece nord-occidentale). Editions Technip., Paris, 306.

[21] Bernoulli, D. and Renz, O. (1970) Jurassic carbonate facies and new ammonite faunas from western Greece: Eclog. Eclogae Geologicae Helvetiae, 63, 573-607.

[22] British Petroleum Company (1971) The Geological Results of Petroleum Exploration in Western Greece: Institute of Geology Subsurface Research, Athens, 10, 73.

[23] Pomoni-Papaioannou, F. (1980) Genesis Diagenesis of Triassic breccia and nodular gypsum of Epirus, I.G.M.E Min. Mineralogical and Petrografical Research, 2, 1-29.

[24] Pomoni-Papaioannou, F. and Tsaila-Monopolis, S. (1982) Petrographical, Sedimentological and Micropaleontological Studies of an Evaporite Outcrop, West of the Ziros Lake (Epirus-Greece). Rivista Italiana di Paleontologia e Stratigraphia, 88, 387399.

[25] Karakitsios, V. and Pomoni-Papaioannou, F. (1998) Sedimentological Study of the Triassic Solution Collapse Breccias of the Ionian Zone (NW Greece). Carbonates and Evaporites, 13, 207-218. https://doi.org/10.1007/BF03176594

[26] Guzzetta, G. (1982) Thin-Skinned Style of Deformation in Epirus. International Symposium on the Hellenic Arc and Trench (HEAT), National Technical University, Athens, 151-175. 
[27] Jenkins, D. (1972) Structural Development of Western Greece. American Association of Petroleum Geologists Bulletin, 56, 128-149.

[28] Sorel, D. and Cushing, M. (1982) Mise en evidence d' un charriage de couverture dans la zone ionienne en Grece occidentale: La nappe d' Akarnanie-Levkas. $C R$ Acad. Sc. Paris, 294, 675-678.

[29] King, G., Tselentis, A., Molnar, P., Roecker, S., Sinvhal, H., Sufleris, C. and Stock, J. (1983) Microearthquake Seismicity and Active Tectonics of Northwestern Greece. Earth and Planetary Science Letters, 66, 279-288. https://doi.org/10.1016/0012-821X(83)90141-3

[30] Pomoni-Papaioannou, F. (1982) Contribution of Dolomites and Evaporates to the Genesis and Trapping of Hydrocarbons. I.G.M.E., Information Bulletin, 6, 15-16.

[31] Pomoni-Papaioannou, F. (1985) The Sedimentology and Depositional Environment of the Triassic Dolomite-Gypsum Facies of Western Greece. Proceedings of the 6 th European Meeting of the Intern, Association Sedimentologist, Athens, 367-368.

[32] Underhill, J. (1985) Neogene and Quaternary Tectonics and Sedimentation in Western Greece. PhD Thesis, University of Wales, Cardiff, 425.

[33] Underhill, J. (1988) Triassic Evaporites and Plio-Quaternary Diapirism in Western Greece. Journal of the Geological Society of London, 145, 209-282. https://doi.org/10.1144/gsjgs.145.2.0269

[34] Underhill, J. (1989) Late Cenozoic Deformation of the Hellenic Foreland, Western Greece. Geological Society of America Bulletin, 101, 613-634. https://doi.org/10.1130/0016-7606(1989)101<0613:LCDOTH>2.3.CO;2

[35] Horner, F. and Freeman, R. (1983) Palaeomagnetic Evidence from Pelagic Limestones for Clockwise Rotation of the Ionian Zone, Western Greece. Tectonophysics, 98, 11-27. https://doi.org/10.1016/0040-1951(83)90208-1

[36] Kissel, C., Laj, C. and Muller, C. (1985) Tertiary Geodynamical Evolution of Northwestern Greece: Paleomagnetic Results. Earth and Planetary Science Letters, 72, 190-204. https://doi.org/10.1016/0012-821X(85)90005-6

[37] Doutsos, T., Kontopoulos, N. and Fridas, D. (1987) Neotectonic Evolution of Northwestern-Continental Greece. Geologische Rundschau, 76, 433-452. https://doi.org/10.1007/BF01821085

[38] Doutsos, T., Kontopoulos, N. and Poulimenos, G. (1988) The Corinth-Patras Rift as the Initial Stage of Continental Fragmentation behind an Active Island Arc (Greece). Basin Research, 1, 177-190. https://doi.org/10.1111/j.1365-2117.1988.tb00014.x

[39] Brooks, M., Clews, J.E., Melis, N.S. and Underhill, J.R. (1988) Structural Development of Neogene Basins in Western Greece. Basin Research, 1, 129-138. https://doi.org/10.1111/j.1365-2117.1988.tb00010.x

[40] Karakitsios, V. and Tsaila-Monopolis, S. (1988) Donnees nouvelles sur les niveaux superieurs (Lias inferieur-moyen) des Calcaires de Pantokrator (zone ionienne moyenne. Epire, Grece continentale). Description des Calcaires de Louros. Revue de Micropaleontologie, 31, 49-55. http://users.uoa.gr/ vkarak/pdf/KARAKITSIOS_1988_d.pdf

[41] Karakitsios, V. and Tsaila-Monopolis, S. (1990) Données nouvelles sur les niveaux inférieurs (Trias supérieur) de la série calcaire ionienne en Epire (Grèce continentale). Conséquences stratigraphiques. Revue de Paleobiologie, 9, 139-147. http://users.uoa.gr/ vkarak/pdf/KARAKITSIOS_1990.pdf

[42] Clew, J. (1989) Structural Controls on Basin Evolution. Neogene to Quaternary of the Ionian Zone, Western Greece. Journal of the Geological Society, 146, 447-457. https://doi.org/10.1144/gsjgs.146.3.0447 
[43] Sorel, D. (1989) L évolution structurale de la Grèce Nord-Occidentale depuis le Miocène dans le cadre géodynamique de l'arc Egéen. Thèse Docteur es Sciences, Uni. Paris XI, Centre d'Orsay.

[44] Karakitsios, V. (1988) Sur la différenciation de la zone ionienne en Epire (Grèce Nord-occidentale). Bulletin of the Geological Society of Greece, 20, 181-196.

[45] Karakitsios, V. (1989) New Data on the Stratigraphy of the Jurassic Formations of the Ionian Series in Epirus (Greece). Tectonic and Palaeogeographical Consequences. Bulletin of the Geological Society of Greece, 23, 59-74.

[46] Karakitsios, V. (1990) Chronologie et geometrie de l'ouverture d'un bassin et de son inversion tectonique: Le bassin ionien (Epire, Grece): (Th. Doct. Univ. Paris IV). Mem. Sc. Terre Univ. P: et M. Curie, Paris, 91-4. 310.

[47] Karakitsios, V. (1991) Etude des paleofailles jurassiques de la zone ionienne (Epire, Grece). 5e Congres de la Soc. geol. de Grece (Mai 1990), Thessalonique. Bulletin of the Geological Society of Greece, 25, 307-318.

[48] Karakitsios, V. (1992) Ouverture et inversion tectonique du basin ionien (Epire. Greece). Annales Geologiques des pays Helleniques, 35, 85-318. http://users.uoa.gr/ vkarak/pdf/KARAKITSIOS_1992_a.pdf

[49] Karakitsios, V. (1995) The Influence of Structure and Halokinesis on Organic Matter Preservation and Thrust System Evolution in Ionian Basin, NW Greece. AAPG Bulletin, 79, 960-980.

[50] Karakitsios, V. (1997) Stratigraphy of Greece. Eds University of Athens, 150.

[51] Rondoyanni, Th., Mettos, A., Paschos, P. and Georgiou, Ch. (1991) New Data on the Stratigraphy and Structure of the Plio-Pleistocene Deposits in the Area of Preveza. Bulletin of the Geological Society of Greece, 25, 57-70.

[52] Waters, D. (1994) The Tectonic Evolution of Epirus, Northwest Greece. PhD. Thesis, University of Cambridge, Cambridge, 248.

[53] Karakitsios, V. and Dermitzakis, M. (1997) Lacunes sédimentaires, discordances et phénomenes paléokarstiques (Pliensbachien-Tithonique) dans la zone ionienne (Epire, Grèce nord-occidentale). Annales Geologiques des pays Helleniques, 37, 847-864.

[54] Nikolaou, E. (2001) Study on the Groundwater Regime of Epirus Karst Aquifers. 2nd E.U. Framework Project, IGME (in Greek).

[55] Paschos, P. (2002) Geodynamic Evolution of the Broader Amvrakikos Area from the Miocene to the Recent (in Greek). PhD Thesis, National Technical University of Athens, Athens, 219.

[56] Nikolaou, C. (1986) Contribution to the Knowledge of the Neogene, the Geology and the Ionian and Pre-Apulian Limits in Relation to the Petroleum Geology Observations in Strophades, Zakynthos and Kephalinia Islands. Ph.D Thesis (Unpublished), University of Athens, Athens, 228.

[57] Caputo, R. and Zouros, N. (1993) Examples of Alpide Deformation from Epirus: Local Anomalies or Need to Re-Evaluate the Amount of Shortening in the Western Hellenides? Bulletin of the Geological Society of Greece, 28, 315-326.

[58] Skourtsis-Coroneou, V. and Manacos, C. (1995) New Micropaleontological Data on the Age of the Onset of the Deposition of the Vigla Limestone Formation. Special Publication of the Geological Society of Greece, 4, 269-274.

[59] Skourtsis-Coroneou, V., Solakious, N. and Constantinidis, I. (1995) Cretaceous Stratigraphy of the Ionian Zone, Hellenides, Western Greece. Cretaceous Research, 16, 539-558.

[60] Kamberis, E., Ioakim, Ch., Tsaila-Monopolis, St., Marnelis, F. and Sotiropoulos, S. 
(1998) Geologic and Paleogeographic Evolution of Western Greece during the Neogene-Quaternary Period in the Geodynamic Setting of the Hellenic Arc. Romanian Journal of Stratigraphy, 78, 63-73.

[61] Kamberis, E., Marnelis, F., Loucoyannakis, M., Maltezou, F., Hirn, A. and Streamers Group (1996) Structure and Deformation of the External Hellenides Based on Seismic Data from Offshore Western Greece. EAGE Special Publication, 5, 207-214.

[62] Getsos, K., Pomoni-Papaioannou, F. and Zelilidis, A. (2004) Triassic Carbonate and Evaporite Sedimentation in Ionian Zone (Western Greece): Palaeogeographic and Palaeoclimatic Implication. Bulletin of the Geological Society of Greece, 36, 699707.

[63] Getsos, K., Pomoni-Papaioannou, F. and Zelilidis, A. (2005) Sedimentological Aspects and Karstification of the Pantokrator Limestones (NW Greece). Proceedings of the 7 th Hellenic Hydrogeological Conference, Athens, 225-232.

[64] Karakitsios, V. and Pomoni-Papaioannou, F. (2009) Triassic Subsurface Evaporates and Outcropping Solution-Collapse Breccias of the Ionian Zone (Western Greece). Guide to Symposium and Field Trip Evaporites: Sedimentology, Evaluation and Economic Significance. Island of Zakynthos, May 28-31 2009. Hellenic Sedimentological Association, 55-58.

[65] Brunn, J.H. (1959) Geological Map of Greece in Scale 1:50,000, "Metsovon" Sheet. Institute of Geology and Mineral Exploration, Athens.

[66] Brunn, J.H. (1960) Geological Map of Greece in Scale 1:50,000, "Pentalofon” Sheet. Institute of Geology and Mineral Exploration, Athens.

[67] Aubouin, J. (1961) Geological Map of Greece in Scale 1:50,000, "Pramanta" Sheet. Institute of Geology and Mineral Exploration, Athens.

[68] Savoyat, E., Monopolis, D., Lalechos, N., Filippakis, N. and Bizon, G. (1963) Geological Map of Greece in Scale 1:50,000, “Thesprotiko" Sheet. Institute of Geology and Mineral Exploration, Athens.

[69] Savoyat, E., Monopolis, D. and Bizon, G. (1966) Geological Map of Greece in Scale 1:50,000, "Peta" Sheet. Institute of Geology and Mineral Exploration, Athens.

[70] Savoyat, E., Monopolis, D., Lalechos, N., Filippakis, N. and Bizon, G. (1970) Geological Map of Greece in Scale 1:50,000, “Agnanta” Sheet. Institute of Geology and Mineral Exploration, Athens.

[71] Perrier, R., Katsikatsos, G., Lalechos, N., Filippakis, N. and Bizon, G. (1966) Geological Map of Greece in Scale 1:50,000, "Paramythia" Sheet. Institute of Geology and Mineral Exploration, Athens.

[72] Savoyat, E., Monopolis, D., Lalechos, N., Filippakis, N. and Bizon, G. (1970) Geological Map of Greece in Scale 1:50,000, "Raftopoulo" Sheet. Institute of Geology and Mineral Exploration, Athens.

[73] Perrier, R., Koukouzas, C. and Bizon, G. (1967) Geological Map of Greece in Scale 1:50,000, "Filiates" Sheet. Institute of Geology and Mineral Exploration, Athens.

[74] Perrier, R., Koukouzas, C. and Bizon, G. (1967) Geological Map of Greece in Scale 1:50,000, "Tsamadas" Sheet. Institute of Geology and Mineral Exploration, Athens.

[75] Perrier, R., Potier, R., Savoyat, E., Koukouzas, C., Monopolis, D., Bizon, J.J. and Bizon, G. (1967) Geological Map of Greece in Scale 1:50,000, “Ioannina” Sheet. Institute of Geology and Mineral Exploration, Athens.

[76] Perrier, R., Koukouzas, C., Bizon, G. and Bizon, J.J. (1968) Geological Map of Greece in Scale 1:50,000, "Doliana" Sheet. Institute of Geology and Mineral Exploration, Athens. 
[77] Perrier, R., Koukouzas, C., Lalechos, N. and Bizon, G. (1968) Geological Map of Greece in Scale 1:50,000, "Klimatia” Sheet. Institute of Geology and Mineral Exploration, Athens.

[78] Perrier, R., Koukouzas, C. and Bizon, G. (1969) Geological Map of Greece in Scale 1:50,000, "Parga" Sheet. Institute of Geology and Mineral Exploration, Athens.

[79] Perrier, R., Koukouzas, C. and Bizon, G. (1969) Geological Map of Greece in Scale 1:50,000, "Sayiadha" Sheet. Institute of Geology and Mineral Exploration, Athens.

[80] Perrier, R., Savoyat, E., Koukouzas, C., Lalechos, N., Filippakis, N. and Bizon, G. (1970) Geological Map of Greece in Scale 1:50,000, “Tsepelovon” Sheet. Institute of Geology and Mineral Exploration, Athens.

[81] Bizon, J.J., Douthe, P., Latreille, M., Perrier, R., Rochet, J., Savoyat, E., Katsikatsos, G. and Bizon, G. (1967) Geological Map of Greece in Scale 1:50,000, "Kanallakion" Sheet. Institute of Geology and Mineral Exploration, Athens.

[82] Latreille, M., Savoyat, E., Monopolis, D., Bizon, J.J. and Bizon, G. (1969) Geological Map of Greece in Scale 1:50,000, “Arta” Sheet. Institute of Geology and Mineral Exploration, Athens.

[83] Koukouzas, C., Perrier, R. and Bizon, G. (1973) Geological Map of Greece in Scale 1:50,000, "Vassilikon-Pogoniani" Sheet. Institute of Geology and Mineral Exploration, Athens.

[84] Koumantakis, J., Matarangas, D., Tsaila-Monopolis, St., Georgiadou, E. and Economou, C. (1980) Geological Map of Greece in Scale 1:50.000, "Panayia" Sheet. Institute of Geology and Mineral Exploration, Athens.

[85] Manacos, K. and Skourtsi-Koronaiou, B. (1983) Geological Map of Greece in Scale 1:50,000, "Myrofyllo" Sheet. Institute of Geology and Mineral Exploration, Athens.

[86] Plastiras, V., Tsaila-Monopolis, St. and Bizon, G. (1985) Geological Map of Greece in Scale 1:50,000, "Chionades-Grammos" Sheet. Institute of Geology and Mineral Exploration, Athens.

[87] Mavridis, A., Manacos, K., Skourtsi-Koronaiou, V. and Dimou, E. (1987) Geological Map of Greece in Scale 1:50,000, "Konitsa" Sheet. Institute of Geology and Mineral Exploration, Athens.

[88] Manacos, K., Skourtsi-Koronaiou, V. and Ioakim, C. (1996) Geological Map of Greece in Scale 1:50,000, "Vonitsa" Sheet. Institute of Geology and Mineral Exploration, Athens.

[89] Mountrakis, D. (2010) Geology and Geotectonic Evolution of Greece. University Studio Press, Thessaloniki (in Greek).

[90] Nikolaou, E. (2010) Update of Epirus Groundwater Data. Hydrogeology Report (V). 3rd E.U. Framework Project IGME, 192 (in Greek).

[91] Runnels, C. and Van Andel, T.H. (1993) A Handaxe from Kokkinopilos, Epirus and Its Implications for the Paleolithic of Greece. Journal of Field Archaeology, 20, 91103. https://doi.org/10.1179/jfa.1993.20.2.191

[92] Ntokos, D., Lykoudi, E. and Rondoyanni, Th. (2016) Geomorphic Analysis in Areas of Low-Rate Neotectonic Deformation: South Epirus (Greece) as a Case Study, Geomorphology Geomorphology, 263, 156-169.

[93] Brousoulis, I., Ioakim, Chr., Kolovos, G. and Papanikos, D. (1999) The Palaeolithic Archaeology of Greece and the Adjacent Areas. "The Ioannina Basin: Geological and Palaeoenvironmental Evolution in Quaternary and Historical Times". Proceed. I.CO.PA.G, 1st Intern.Cont. (The Paaleolithic Archaeology of Greece and Adjacent areas), Ioannina, September 1994, 87-96. http://www.jstor.org/stable/40960216

[94] Doutsos, T., Koukouvelas, I., Zelilidis, A. and Kontopoulos, N. (1994) Intraconti- 
nental Wedging and Post-Orogenic Collapse in the Mesohellenic Trough. Geologische Rundschau, 83, 257-275.

[95] Avramidis, P., Zelilidis, A., Vakalas, I. and Kontopoulos, N. (2002) Interactions between Tectonic Activity and Eustatic Sea-Level Changes in the Pindos and Mesohellenic Basins, NW Greece. Journal of Petroleum Geology, 25, 53-82. https://doi.org/10.1111/j.1747-5457.2002.tb00099.x

[96] IFP (1964) Bassin de Thessalie-Grevena. Synthese petroliere. Ministere de l'Industrie de Grece, Athene.

[97] Aubouin, J., Bonneau, M., Celet, P., Charvet, J., Ciement, B., Degardin, J.M., Dercourt, J., Ferrière, J., Fleury, J.J., Guernet, C., Maillot, H., Mania, J.H., Mansy, J.L., Terry, J., Thiébault, P., Tsofilias, P. and Verrrieux, J.J. (1970) Contribution à la géologié des Hellénides: Le Gavrovo, Le Pinde et la zone ophiolitique Subpélagonienne. Annales de la Societe Geologique du Nord, 90, 277-306.

[98] Mountrakis, D. (1985) Geology of Greece, 207 (in Greek).

[99] Zouros, N. (1993) Study of the Tectonic Structures Connected with the Pindos Nappe in Epirus (NW Greece). PhD Thesis, University of Thessaloniki, Thessaloni$\mathrm{ki}, 401$.

[100] Fleury, J.J. (1980) Les zones de Gavrovo-Tripolitza et du Pinde-Olonos (Grèce continentale et Péloponnèse du Nord). Evolution d'une plateforme et d'une bassin dans le cadre alpin. Societe Geologique du Nord, 4, 648.

[101] Neumann, P. and Zacher, W. (2004) The Cretaceous Sedimentary History of the Pindos Basin (Greece). International Journal of Earth Sciences (Geologische Rundschau), 93, 119-31. https://doi.org/10.1007/s00531-003-0358-3

[102] Rassios, A., Grivas, E., Konstaniopoulou, G. and Vacondios, L. (1994) The Geometry of Structures Forming Around the Ductile-Brittle Transition in the VourinosPindos-Cnhris Oceanic Slab. Bulletin of the Geological Society of Greece, 30, 109121.

[103] Zappaterra, E. (1990) Carbonate Paleogeographic Sequences of the Peri-Adriatic Region. Bulletin of the Geological Society of Italy, 109, 5-20.

[104] Zappaterra, E. (1994) Source-Rock Distribution of the Periadriatic Region. AAPG Bulletin, 78, 333-354.

[105] Dragastan, O., Papanikos, D. and Papanikos, P. (1985) Foraminiferes. Algues et microproblematica du Trias de Messopotamos. Epire (Grece continentale). Ret. Micropaleont, 27, 244-248.

[106] Vekios, P. (1979) Preliminary Report on the Bitoumenal Phosphoprite in the Faraggi Region of Epirus (in Greek). Unpublished Report, IGME.

[107] Nikolaou, C. (1988) Neo-Diapiric Movements of Triassic Evaporites in Zakynthos and Strophades, Bulletin of the Geological Society of Greece, 20, 83-99.

[108] Dommergues, J.-L., Karakitsios, V., Meister, C. and Bonneau, M. (2002) New Ammonite Data about the Earliest Syn-Rift Deposits (Lower Jurassic) in the Ionian Zone of NW Greece (Epirus). Neues Jahrbuch fur Geologie und Palaeontologie, Abhandlungen, 223, 299-316.

[109] Walzebuck, J.P. (1982) Bedding Types of the Toarcian Black Shales in NW Greece. In: Einsel, G. and Seilacher, A., Eds., Cyclic and Event Stratification, Springer-Verlag, New York, 512-525. https://doi.org/10.1007/978-3-642-75829-4_41

[110] Karakitsios, V. and Velitzelos, E. (1997) Ammonitico Rosso and Posidonia Beds: Two Important Geological Formations of Epirus. Natural Monuments and Geological Heritage, Molyvos, Lesvos, 43-44 (Abstract).

[111] Baumgartner, T.R., Danelian, T., Dumitrica, P., Gorican, S., Jud, R., O’Dogherty, L., 
Carter, B., Conti, M., De Wever, P., Kito, N., Marcucci, M., Matsuoka, A., Murchey, B. and Urquart, E. (1993) Middle Jurassic-Early Cretaceous Radiolarian Biochronology of Tethys: Implications for the Age of Radiolarites in the Hellenides (Greece). Bulletin of the Geological Society of Greece, 28, 13-23.

[112] Danelian, T. (1989) Radiolaires Jurassiques de la zone ionienne (Epire. Grece). Paleontologie, stratigraphie, implications paleogeographiques. These. Univ. P. et M. Curie, Paris, 260.

[113] Karakitsios, V., Danelian, T. and DeWever, P. (1988) Datations par les Radiolaires à Filaments, Schistes à Posidonies superierieurs et Calcaires de Vigla (zone Ionienne, Epire, Grèce) du Callovien au Tithonique terminal. Comptes Rendus de P Academie des Sciences, Paris, Series II, 306, 367-372.

[114] Vekios, P. and Chiotis, E. (1993) Palaeogeographic Conditions of the Formation of Phosphorites and Oil Hosting Rocks in Epirus. Contribution to the Investigation of Phosphorites and Hydrocarbons (in Greek). Bulletin of the Geological Society of Greece, 28, 535-549.

[115] Karakitsios, V. and Koletti, L. (1991) Stratigraphy of the Basal Vigla Limestones (Ionian Zone-Western Greece) Based on Nannoplankton. Paleogeographic Consequences. Proceedings of $4^{\text {th }}$ International Nannoplankt on Association Conference, Prague, 8-14 September 1991, 47.

[116] Danelian, T., De Wever, P. and Azéma, J. (1997) Palaeoceanographic Significance of New and Revised Palaeontological Datings for the Onset of Vigla Limestone Sedimentation in the Ionian Zone of Greece. Geological Magazine, 134, 869-872. https://doi.org/10.1017/S0016756897007553

[117] Serjani, A. (1991) Aspects of Thrust Tectonics from West to East in Kurvaleshi Region (in Albanian with English Abstract). Buletini i shkencave gjeologjike, 1, 213 220.

[118] Pomoni-Papaioannou, F. (2001) Lithostratigraphy-Sedimentology of Upper Cretaceous Phosphatic Formations of Ionian Zone, Mechanism of Phosphogenesis-Paleotectonic Frame. Monography, Gaia, 7, 182.

[119] Bornovas, G. (1960) Observations nouvelles sur la geologie des zones preapulienne et Ionienne (Grece occidentale). Paris, B. S. G. F., (7) II, 410-414.

[120] Robertson, A.H.F., Clift, P.D., Degnan, P.J. and Jones, G. (1991) Palaeogeographic and Palaeotectonic Evolution of the Eastern Mediterranean Neotethys. Palaeogeography, Palaeoclimatology, Palaeoecology, 87, 289-343. https://doi.org/10.1016/0031-0182(91)90140-M 
Submit or recommend next manuscript to SCIRP and we will provide best service for you:

Accepting pre-submission inquiries through Email, Facebook, LinkedIn, Twitter, etc. A wide selection of journals (inclusive of 9 subjects, more than 200 journals)

Providing 24-hour high-quality service

User-friendly online submission system

Fair and swift peer-review system

Efficient typesetting and proofreading procedure

Display of the result of downloads and visits, as well as the number of cited articles Maximum dissemination of your research work

Submit your manuscript at: http://papersubmission.scirp.org/

Or contact ijg@scirp.org 